\title{
The chloride anion as a signalling effector
}

\author{
Ángel G. Valdivieso ${ }^{1,2}$ and Tomás A. Santa-Coloma ${ }^{1,2, *}$
}

${ }^{1}$ Laboratory of Cellular and Molecular Biology, Institute for Biomedical Research (BIOMED), School of Medical Sciences, Pontifical Catholic University of Argentina, Alicia Moreau de Justo 1600, Buenos Aires 1107, Argentina

${ }^{2}$ Laboratory of Cellular and Molecular Biology, Institute for Biomedical Research (BIOMED), The National Scientific and Technical Research Council of Argentina (CONICET), Alicia Moreau de Justo 1600, Buenos Aires, 1107, Argentina

Running title: Chloride anion as signalling effector

*Author for correspondence at address 1 (E-mail: tomas_santacoloma@uca.edu.ar; Tel./Fax: 5411-4338-0886).

\section{ABSTRACT}

The specific role of the chloride anion $\left(\mathrm{Cl}^{-}\right)$as a signalling effector or second messenger has been increasingly recognized in recent years. It could represent a key factor in the regulation of cellular homeostasis. Changes in intracellular $\mathrm{Cl}^{-}$ concentration affect diverse cellular functions such as gene and protein expression and activities, post-translational modifications of proteins, cellular volume, cell cycle, cell proliferation and differentiation, membrane potential, reactive oxygen species levels, and intracellular/extracellular $\mathrm{pH} . \mathrm{Cl}^{-}$also modulates functions in different organelles, 
including endosomes, phagosomes, lysosomes, endoplasmic reticulum, and mitochondria. A better knowledge of $\mathrm{Cl}^{-}$signalling could help in understanding the molecular and metabolic changes seen in pathologies with altered $\mathrm{Cl}^{-}$transport or under physiological conditions. Here we review relevant evidence supporting the role of $\mathrm{Cl}^{-}$as a signalling effector.

Key words: chloride anion, $\mathrm{Cl}^{-}$, second messenger, inflammation, proinflammatory signal, oxidative stress, intracellular signalling, signal transduction, CFTR.

\section{CONTENTS}

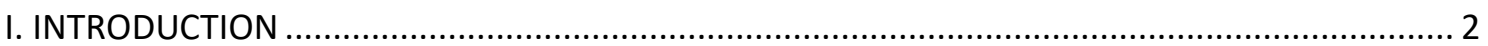

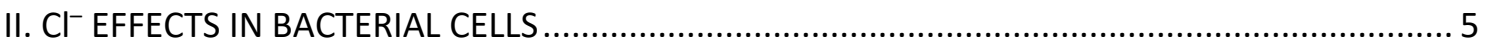

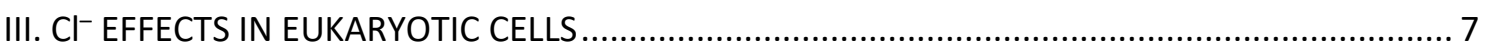

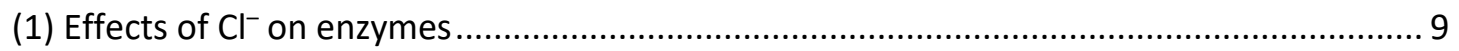

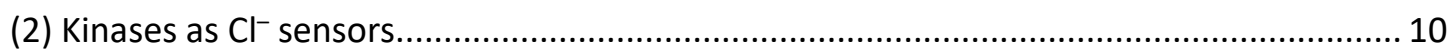

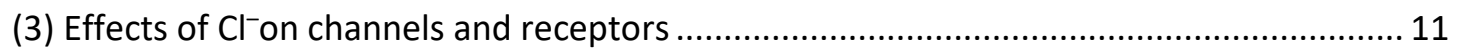

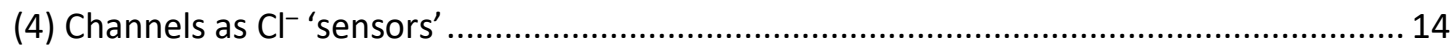

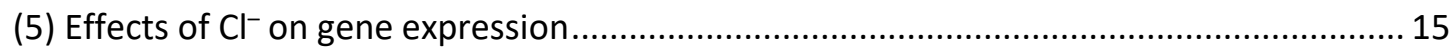

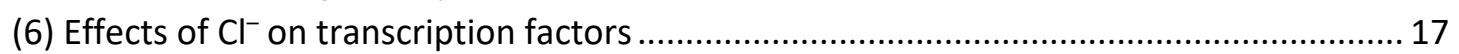

IV. CELLULAR PROCESSES REGULATED BY INTRACELLULAR CHLORIDE CHANGES....................... 18

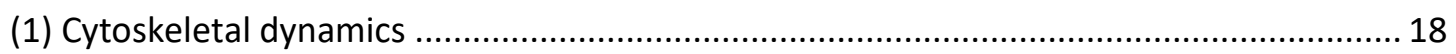

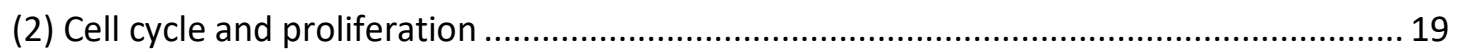

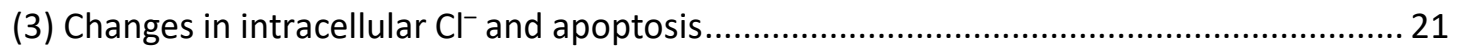

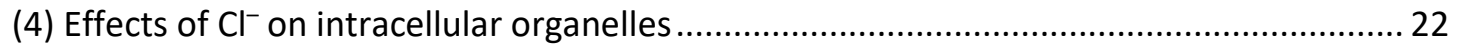

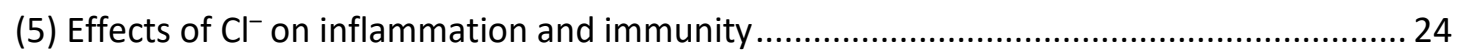

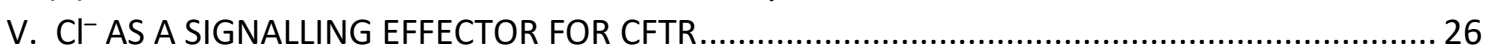

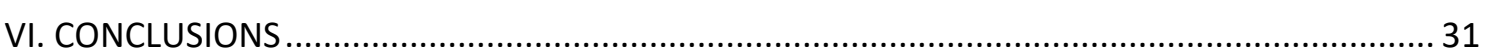

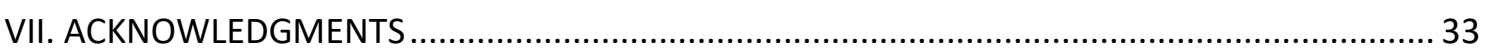

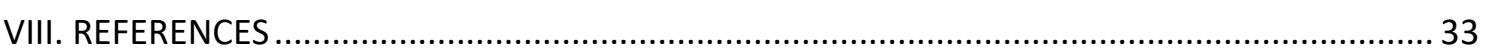

\section{INTRODUCTION}

The chloride anion $\left(\mathrm{Cl}^{-}\right)$, the most abundant anion in nature (Berend, van

Hulsteijn \& Gans, 2012; Bonifacie et al., 2008; Turekian, 1968), is involved in general 
biophysical processes such as osmotic equilibrium (Barrett et al., 2015; Houssay, Lewis \& Orias, 1951; West, 1997; Willumsen, Davis \& Boucher, 1994) and the transport of water and salt through epithelia (Hubner \& Jentsch, 2008; Jentsch, Maritzen \& Zdebik, 2005; Lee et al., 2012). However, in addition to these general functions, $\mathrm{Cl}^{-}$has other specific roles, acting as a signalling effector or modulator of specific cell functions, including cell volume (Pedersen, Hoffmann \& Novak, 2013; Treharne, Crawford \& Mehta, 2006), membrane potential (Crutzen et al., 2016; Funabashi et al., 2010; Liang et al., 2009), intracellular pH (Paredes et al., 2016) and extracellular pH (Massip-Copiz \& Santa-Coloma, 2018; Valdivieso et al., 2019). It also affects the function of endosomes (Matsuda et al., 2010; Miller et al., 2007), phagosomes (Painter et al., 2010; Riazanski et al., 2015), endoplasmic reticulum (ER) (Barro-Soria et al., 2010), and mitochondria (Nunes et al., 2015; Tomaskova \& Ondrias, 2010). It might have even more specific roles, perhaps as a second messenger (Orlov \& Hamet, 2006), affecting the activity of channels (Bachhuber et al., 2005; Bekar \& Walz, 1999; Broadbent et al., 2015; Sirianant et al., 2016; Succol et al., 2012), and enzymes (Bazua-Valenti et al., 2015; Huang \& Cheng, 2015; Piala et al., 2014; Terker et al., 2016). It is also involved in the regulation of specific genes (Clauzure et al., 2017; Miyazaki et al., 2008; Roessler \& Muller, 2002; Sanders, Venema \& Kok, 1997; Valdivieso et al., 2016). Some examples of proteins and genes modulated by $\mathrm{Cl}^{-}$are provided in Tables 1 and 2 .

An early record of $\mathrm{Cl}^{-}$effects in pathophysiology can be found in medieval reports describing the symptoms of what we know today as cystic fibrosis, although then attributing the disease to 'being bewitched' (Busch, 1990). Another interesting historical precedent evidencing the relevance of $\mathrm{Cl}^{-}$functions in physiology are early observations on the stomach fluids and initial physiological studies carried out in the 
18th century (reviewed in (Kousoulis et al., 2012). In the 19th century, Sydney Ringer (DeWolf, 1977), the developer of the popular 'Ringer's salt solution' (Miller, 2004; Ringer, 1883), was a pioneer in studies concerning the possible role of $\mathrm{NaCl}$ in physiology. One of his observations was the possible correlation between "the heat of the body" and the amount of $\mathrm{NaCl}$ excreted (Ringer, 1859).

In 1823, William Prout (1785-1850) identified $\mathrm{HCl}$ as the main acid in the stomach, determining $\mathrm{Cl}-$ and $\mathrm{H}^{+}$concentrations by titrating with silver nitrate and caustic potash solution (KOH) (Prout, 1974) [reviewed in (Kousoulis et al., 2012; Rosenfeld, 2003)]. However, his work, presented at the Royal Society of London, was not widely accepted for many years. Claude Bernard (1813-1878), the notable French physiologist, believed that the main acid in the stomach was lactic acid (Baron, 1973). This disagreement led to more than 100 years of controversy, until Prout's results were finally accepted [reviewed in (Baron, 1973; Kousoulis et al., 2012)].

Another interesting precedent is the discovery of angiotensin and the $\mathrm{Cl}^{-}$ dependency of angiotensin-converting enzyme (ACE). J.B. Señorans (1859-1933) studied under Bernard's disciples and continued to promote his physiological interests (Charreau, 2016; Houssay \& Buzzo, 1937), among them, the problem of hypertension (Fasciolo, Houssay \& Taquini, 1938; Irving, 1965). This led eventually to the discovery of the renal factor involved in hypertension, named 'hypertensin' (BraunMenendez, 1939; Fasciolo et al., 1938; Fasciolo, 1990). The influence of Bernard's ideas was also strong in the USA (Olmsted, 1935), leading to the parallel discovery of the same hypertensive factor in the Lilly Laboratory for Clinical Research in Indianapolis, there named 'angiotonin' (Page \& Helmer, 1940). Finally, both laboratories agreed to name the factor 'angiotensin' (Menendez et al., 1943; Smulyan \& Villarreal, 2019). In 1954, the angiotensin-converting enzyme (ACE) was 
characterized and interestingly, was found to be activated by $\mathrm{Cl}^{-}$(Skeggs et al., 1954; Skeggs, Kahn \& Shumway, 1956). Bünning (1983) described the possible catalytic mechanism of ACE and the effects of $\mathrm{Cl}^{-}$. Knowledge of its three-dimensional (3D) structure allowed a better understanding of how $\mathrm{Cl}^{-}$could function in ACE activation, although the exact sites of $\mathrm{Cl}^{-}$action and specificity are still a matter of debate (Masuyer et al., 2014; Zhang, Wu \& Xu, 2013). It is now thought that $\mathrm{Cl}^{-}$, and not only $\mathrm{Na}^{+}$, may have an important role in hypertension (McCallum, Lip \& Padmanabhan, 2015). The binding of $\mathrm{Cl}^{-}$to ACE has been also useful in studies investigating the effects of $\mathrm{Cl}^{-}$in Photosystem II, $\alpha$-amylase and other $\mathrm{Cl}^{-}$-modulated enzymes (Coleman, 1990).

The aim of this review is to update knowledge regarding the specific functions of the chloride anion as a signalling effector, acting as a modulator of other signals, as a specific ligand for certain enzymes and proteins, or as a second messenger for receptors and channels. We will not review the specific roles of $\mathrm{Cl}^{-}$channels in cell signalling, physiology and pathophysiology, which have been extensively reviewed elsewhere (Alvarez-Leefmans \& Delpire, 2010; Hartzell, 2010; Kunzelmann, 2016; Kunzelmann et al., 2016; Pedersen et al., 2016; Sabirov et al., 2016; Sala-Rabanal et al., 2015; Wanitchakool et al., 2016).

\section{II. $\mathrm{Cl}^{-}$EFFECTS IN BACTERIAL CELLS}

One of the earliest studies assigning a possible specific role to $\mathrm{Cl}^{-}$came from work on bacteria. MacLeod \& Onofrey (Macleod \& Onofrey, 1956; Macleod \& Onofrey, 1957) performed studies on isolated marine bacteria and suggested that $\mathrm{Cl}^{-}$might have a specific function, since these bacteria needed $\mathrm{Cl}^{-}$for growth. Subsequently, Sanders et al. (Sanders et al., 1998), using a lacZ gene reporter, showed the existence of a promoter that was sensitive to $\mathrm{Cl}^{-}$in Lactococcus lactis. Although the mechanisms by 
which $\mathrm{Cl}^{-}$was able to induce the activation of this promoter were unknown, it was established that this regulation was independent of osmolarity, ionic strength and $\mathrm{Na}^{+}$ concentration (Sanders et al., 1998). They also reported the nucleotide sequence and functional analysis of two genes transcribed from this promoter, $\operatorname{gad} C$ and $\operatorname{gadB}$, that conferred $\mathrm{Cl}^{-}$-inducible acid resistance to Lactococcus lactis. GadB showed similarity to glutamate decarboxylases and $\mathrm{GadC}$ was homologous to putative glutamate-gammaaminobutyrate antiporters (Sanders et al., 1998b). These functions were later confirmed and constitute the basis for the mechanism involved in the $\mathrm{pH}$ resistance of bacteria able to transit through the gut (De Biase \& Pennacchietti, 2012). Gut et al. (2006) showed that $\mathrm{Cl}^{-}$was an allosteric activator of glutamate decarboxylase and identified the halidebinding sites, showing how halide binding is responsible for activation of the enzyme.

Roessler \& Muller (Roessler \& Muller, 2002) proposed that $\mathrm{Cl}^{-}$can act as an environmental signal effector that regulates gene expression in the halophilic bacterium Halobacillus halophilus. These authors reported $\mathrm{Cl}^{-}$dependency of the expression of fliC (encoding flagellin, the major subunit of the flagellum) involving a chloride regulon (Roessler \& Muller, 2002). Other $\mathrm{Cl}^{-}$-dependent proteins were identified in addition to FliC, suggesting the existence of a chloride regulatory network, at least in $H$. halophilus (Roessler \& Muller, 2002; Sewald et al., 2007). These observations suggested an important role of $\mathrm{Cl}^{-}$in signal transduction, modulating gene expression and protein synthesis in bacteria.

Other studies in prokaryotic organisms showed the importance of $\mathrm{Cl}^{-}$in the metabolism of different groups of halophilic prokaryotes, both archaeal and bacterial [reviewed by Müller \& Oren (Muller \& Oren, 2003; Roessler, Sewald \& Muller, 2003)]. However, apart from the above-mentioned work, there has been relatively little interest in the effects of $\mathrm{Cl}^{-}$in bacteria, an area which needs further development. 


\section{Cl- EFFECTS IN EUKARYOTIC CELLS}

In eukaryotic cells, intracellular chloride concentration $\left(\left[\mathrm{Cl}^{-}\right]_{\mathrm{i}}\right)$ may play a role in the regulation of different proteins (Cigic \& Pain, 1999; Coleman, 1990; Feller et al., 1996; Liu et al., 2001; Sangan et al., 2002; Treharne, Marshall \& Mehta, 1994; Yuan et al., 2000) and genes (Cheng et al., 2000; Niisato, Taruno \& Marunaka, 2007; Succol et al., 2012; Valdivieso et al., 2016; Yang et al., 2000). These intracellular regulatory functions of $\mathrm{Cl}^{-}$might have significant effects on important cellular processes such as proliferation (Klausen et al., 2010; Lai, Chen \& Nishi, 2003; Miyazaki et al., 2008; Ohsawa et al., 2010), apoptosis (Kunzelmann, 2016; Wanitchakool et al., 2016), inflammation (Maldonado et al., 1991; Yang et al., 2012; Yang et al., 2000) and immunity (Lai et al., 2003; Menegazzi et al., 2000). The study of $\mathrm{Cl}^{-}$in mammalian cells has been strongly motivated by the existence of several pathologies related to altered $\mathrm{Cl}^{-}$transport or $\mathrm{Cl}^{-}$homeostasis (Jentsch et al., 2005; Planells-Cases \& Jentsch, 2009; Puljak \& Kilic, 2006), including cystic fibrosis (CF) (Quinton, 1983), congenital myotonia (Koch et al., 1992; Pusch, 2002), Bartter syndrome (Birkenhager et al., 2001; Estevez et al., 2001; Simon et al., 1997), kidney failure (Birkenhager et al., 2001), deafness (Birkenhager et al., 2001), and the bone disease osteopetrosis (Kornak et al., 2001). However, for many years $\mathrm{Cl}^{-}$was considered an inert anion since in the model systems initially used - erythrocytes and muscle cells - the resting permeability was very high and, therefore, $\mathrm{Cl}^{-}$was at electrochemical equilibrium even in the presence of active $\mathrm{Cl}^{-}$transport (Duran et al., 2010). Later, despite the clear inhibitory effects of enhanced $\mathrm{Cl}^{-}$conductance on gamma aminobutyric acid (GABA) signalling, the effects of $\mathrm{Cl}^{-}$did not attract much attention (Duran et al., 2010). Thus, until recently, $\mathrm{Cl}^{-}$was rather neglected as a 
possible signalling effector. Clearly, a deep understanding of the mechanisms involved in protein and gene regulation by $\mathrm{Cl}^{-}$is important to understand better the pathologies associated with different $\mathrm{Cl}^{-}$channels (channelopathies) (Poroca, Pelis \& Chappe, 2017; Statland, Phillips \& Trivedi, 2014; Suetterlin, Mannikko \& Hanna, 2014). The role of $\mathrm{Cl}^{-}$channels in disease has been extensively reviewed elsewhere (Abeyrathne, Chami \& Stahlberg, 2016; Hoffmann et al., 2015; Ito, 2016; Kamaleddin, 2018; Kunzelmann \& Mall, 2002; Pedemonte \& Galietta, 2014; Poroca et al., 2017; Whitlock \& Hartzell, 2016). The early history of the role of $\mathrm{Cl}^{-}$in muscle was recently reviewed by Hutter (Hutter, 2017).

In eukaryotic cells, several studies focused initially on the effects of hypotonicity on gene expression regulation by incubating cells in media with low $\mathrm{Cl}^{-}$concentrations (Cheng et al., 2000; Niisato et al., 2007; Rozansky et al., 2002; Yang et al., 2000). This approach uncovered the osmoregulation of several genes, which could be mediated by cytosolic $\mathrm{Cl}^{-}$changes or not, depending on the strategy used (hyper-, iso- or hypoosmotic media). Later, the focus changed to include more specific $\mathrm{Cl}^{-}$effects, under isosmotic and isovolumetric conditions, using a double-ionophore strategy (nigericin and tributyltin) (Clauzure et al., 2017; Nunes et al., 2015; Valdivieso et al., 2016; Zhang et al., 2018) previously used to measure $\left[\mathrm{Cl}^{-}\right]_{\mathrm{i}}(\mathrm{Chao}$ et al., 1989; Krapf, Berry \& Verkman, 1988; Valdivieso et al., 2011). It should be pointed out here that it is important to distinguish the less-specific ionic effects of $\mathrm{Cl}^{-}$, such as changes in ionic strength and osmolality, from more-specific effects mediated by $\mathrm{Cl}^{-}$channels and transporters, which modify the $\mathrm{Cl}^{-}$concentration indirectly and affect, for example, cellular volume, membrane potential and intracellular $\mathrm{pH}$. It is also important to distinguish these indirect effects from the highly specific and direct effects of $\mathrm{Cl}^{-}$on the structure of enzymes, acting close to or inside their active sites. The most informative 
studies regarding the influence of $\mathrm{Cl}^{-}$in different proteins are described below and summarized in Table 1.

\section{(1) Effects of $\mathrm{Cl}^{-}$on enzymes}

Changes in the $\left[\mathrm{Cl}^{-}\right]_{\mathrm{i}}\left(\Delta\left[\mathrm{Cl}^{-}\right]_{\mathrm{i}}\right)$ or direct effects of $\mathrm{Cl}^{-}$have been postulated as regulatory factors of many different enzymes and proteins (Cigic \& Pain, 1999; Liu et al., 2001; Moriyama \& Nelson, 1987; Nakajima, Sugimoto \& Kurachi, 1992; Pazoles et al., 1980; Prange et al., 2001).

Direct effects of $\mathrm{Cl}^{-}$on enzymes have been described for the photosynthetic oxygenevolving complex (OEC) of Photosystem II (PSII) (Pokhrel, McConnell \& Brudvig, 2011), ACE (Bunning, 1983; Masuyer et al., 2014; Skeggs et al., 1956) and $\alpha$-amylase (Feller et al., 1996), where the $\mathrm{Cl}^{-}$binding site has been identified. Coleman (1990) reviewed the initial studies regarding $\mathrm{Cl}^{-}$binding proteins. Comparing similarities between the structures and catalytic mechanisms of the $\mathrm{OEC}$ with other $\mathrm{Cl}^{-}$-dependent enzymes, Coleman (1990) suggested that the mechanism by which $\mathrm{Cl}^{-}$regulates the activity of target enzymes could involve effects on the ionization state of residues in the active site or effects on the stabilization of a particular conformation. More recently, Pokhrel et al. (Pokhrel et al., 2011), using new structural information about PSII, and comparing with ACE and $\alpha$-amylase, described novel and detailed interactions of $\mathrm{Cl}^{-}$ binding sites. These enzymes are activated by $\mathrm{Cl}^{-}$, and the presence of a positively charged Arg or Lys is crucial for the interaction with the anion. In the absence of $\mathrm{Cl}^{-}$, the residues D2 and K317 of PSII form a salt bridge (D2:K317) together with D1:D61 (and/or D1:E333), causing a conformational shift in D1:D61 that affects its ability to act as a $\mathrm{H}^{+}$acceptor. The exact site of $\mathrm{Cl}^{-}$action in ACE is still subject to debate (Masuyer et al., 2014; Pokhrel et al., 2011; Zhang et al., 2013). 
Interest in characterizing the mechanisms of $\mathrm{Cl}^{-}$binding to proteins has increased in recent years. Carugo (Carugo, 2014) performed a bioinformatic analysis using data from the Protein Data Bank (www.rcsb.org) to identify the preferred amino acids and the coordination stereochemistry occurring in interactions with $\mathrm{Cl}^{-}$. It was concluded that the first coordination spheres of $\mathrm{Cl}^{-}$are mainly formed by hydrogen bond donors and that Arg interacts more frequently than Lys, with a coordination number of 4 or 5 depending on the protein. This study could be of value to analyse new protein crystal structures containing $\mathrm{Cl}^{-}$and to identify possible $\mathrm{Cl}^{-}$binding sites (Carugo, 2014). Changes in extracellular chloride concentration $\left(\left[\mathrm{Cl}^{-}\right]_{\mathrm{e}}\right)$ or $\left[\mathrm{Cl}^{-}\right]_{\mathrm{i}}$ may directly affect many enzymes.

\section{(2) Kinases as $\mathrm{Cl}^{-}$sensors}

Following the precedent set by other authors, we here use 'sensor(s)' to describe $\mathrm{Cl}^{-}$-dependent proteins that are involved in signalling pathways, to distinguish them from metabolic enzymes or structural proteins that may also respond to $\mathrm{Cl}^{-}$changes. Treharne et al. (Treharne et al., 1994) reported the presence of a $\mathrm{Cl}^{-}$-dependent GTPutilizing protein kinase in the apical membrane of human respiratory epithelial cells, and postulated a molecular mechanism for the transduction of $\left[\mathrm{Cl}^{-}\right]$into a guanosine $5^{\prime}-$ triphosphate-selective protein kinase signal. Later, they suggested the involvement of a protein histidine kinase, the nucleoside diphosphate kinase (NDPK); however, a $\mathrm{Cl}^{-}$sensing mechanism could not be demonstrated with the purified kinase or by using specific inhibitors (Treharne et al., 2006). More recently, several reports focused on a role of the with-no-lysine kinases (WNK) family as ' $\mathrm{Cl}^{-}$-sensing kinases' (BazuaValenti et al., 2015; Huang \& Cheng, 2015; Piala et al., 2014; Terker et al., 2016). WNKs are a family of serine-threonine kinases (WNK1-4) (Xu et al., 2000) involved in 
the phosphorylation of several cotransporters, mainly those transporting $\mathrm{Na}^{+}, \mathrm{K}^{+}$, and $\mathrm{Cl}^{-}(\mathrm{NKCC}), \mathrm{Na}^{+}$and $\mathrm{Cl}^{-}(\mathrm{NCC})$, and $\mathrm{K}^{+}$and $\mathrm{Cl}^{-}(\mathrm{KCC})$ (for recent reviews see (Huang \& Cheng, 2015; Piala et al., 2014; Shekarabi et al., 2017; Terker et al., 2016). WNK1 and WNK4 negatively regulate cystic fibrosis trans-membrane conductance regulator (CFTR) activity (Yang et al., 2007). It has been shown that $\mathrm{Cl}^{-}$binds to the kinase domain of WNK1 inhibiting its activity (Piala et al., 2014) and that WNK4 senses $\left[\mathrm{Cl}^{-}\right]_{\mathrm{i}}$ (Chen et al., 2019). The discovery that WNK kinases act as intracellular $\mathrm{Cl}^{-}$sensors opens a new avenue in the study of the role of $\mathrm{Cl}^{-}$as a second messenger and reveals another pathway of $\mathrm{Cl}^{-}$signalling through the activation of these kinases.

Zhang et al. (Zhang et al., 2018) recently showed that serum glucocorticoid regulated kinase 1 (SGK1) activity is under $\mathrm{Cl}^{-}$modulation and that this kinase might be involved in the mechanism by which $\mathrm{Cl}^{-}$acts as a proinflammatory signal (Clauzure et al., 2017; Zhang et al., 2018). Intriguingly, increasing $\mathrm{Cl}^{-}$concentration has opposing effects on WNK1 and SGK1 activities, decreasing the activity of WNK1 and increasing that of SGK1. Direct effects of $\mathrm{Cl}^{-}$on SGK1 structure have not yet been reported, although in vitro incubation with different $\mathrm{Cl}^{-}$concentrations supports a direct dependency with $\mathrm{Cl}^{-}$(Zhang et al., 2018). However, until the effects of $\mathrm{Cl}^{-}$on the 3D structure of SGK1 are demonstrated, an indirect effect of $\left[\mathrm{Cl}^{-}\right]_{\mathrm{i}}$ changes affecting SGK1 activity or expression cannot be ruled out.

\section{(3) Effects of $\mathrm{Cl}^{-}$on channels and receptors}

Several channels and transporters regulate $\left[\mathrm{Cl}^{-}\right]_{\mathrm{i}}($ Krall et al., 2015; Kunzelmann et al., 2011b; Kunzelmann, 2015; Oh \& Jung, 2016; Plans, Rickheit \& Jentsch, 2009; Stauber, 2015), and conversely, changes in $\left[\mathrm{Cl}^{-}\right]_{\mathrm{i}}$ regulate their activity (Broadbent $e t$ al., 2015; Choi et al., 2001; Plested, 2011; Xie \& Schafer, 2004; Yu et al., 2013). 
One such transporter regulated by $\left[\mathrm{Cl}^{-}\right]_{\mathrm{i}}$ is the $\mathrm{Na}^{+}-\mathrm{K}^{+}-2 \mathrm{Cl}^{-}$cotransporter (NKCC1/SLC12A2). This is a secondary active transporter that contributes to the accumulation of $\mathrm{Cl}^{-}$above its Nernst equilibrium potential (against its electrochemical gradient) by using the potential energy stored in the $\mathrm{Na}^{+}$chemical gradient (Russell, 2010). Thus, in many epithelial cells NKCC1 inhibition with bumetanide significantly reduces $\left[\mathrm{Cl}^{-}\right]_{\mathrm{i}}\left(\right.$ Orlov \& Hamet, 2006). The accumulated $\mathrm{Cl}^{-}$creates a feedback signal that inhibits NKCC1 (cell shrinkage produces the same effect). That ATP is an absolute requirement was demonstrated in squid giant axons (Russell, 1979). Lytle \& Forbush (Lytle \& Forbush, 1992) showed that this was due to phosphorylation in serine and threonine residues. (Haas, McBrayer \& Lytle, 1995) found $\left[\mathrm{Cl}^{-}\right]_{\mathrm{i}}$-dependent phosphorylation of $\mathrm{NKCC} 1$ in primary cultures of dog tracheal epithelial cells and Russell (Russell, 2000; Russell, 2010) showed that increasing $\left[\mathrm{Cl}^{-}\right]_{\mathrm{i}}$ from 20 to $150 \mathrm{mM}$ produced a dramatic decrease in the activity of this cotransporter, reducing both its phosphorylation and activation. Similar effects were observed with the NCC cotransporter (Pacheco-Alvarez et al., 2006). The kinase responsible for this phosphorylation was shown to be serine/threonine kinase 39 (STK39)/ Ste20-related proline alanine-rich kinase (SPAK /PASK) (Dowd \& Forbush, 2003; Piechotta, Lu \& Delpire, 2002). Further studies reported that WNK4 was a modulator of NKCC1 upstream of SPAK and Odd-Skipped Related Transcription Factor 1 (OSR1) (Gagnon, England \& Delpire, 2006a; Gagnon, England \& Delpire, 2006b; Shekarabi et al., 2017). WNK kinases were then shown to be $\mathrm{Cl}^{-}$sensor molecules inhibited by high $\left[\mathrm{Cl}^{-}\right]_{\mathrm{i}}$ (Huang \& Cheng, 2015; Pacheco-Alvarez \& Gamba, 2011; Piala et al., 2014; Terker et $a l ., 2016$ ), leading to NKCC1 dephosphorylation by phosphatases (reviewed in (Shekarabi et al., 2017), explaining the ability of intracellular $\mathrm{Cl}^{-}$to inhibit $\mathrm{NKCC} 1$. The WNK-SPAK pathway also modulates cell volume and the activity of the 
electrogenic sodium bicarbonate cotransporter 1 ( $\mathrm{NBCe} 1$ ), the $\mathrm{Cl}^{-} / \mathrm{HCO}_{3}{ }^{-}$exchanger family SLC26A(1,6,7), and the $\mathrm{Cl}^{-}$channel CFTR (Shekarabi et al., 2017).

Chloride also affects the epithelial sodium channel (ENaC). The inhibition of the ENaC by the CFTR in Xenopus laevis oocytes requires high $\left[\mathrm{Cl}^{-}\right]_{\mathrm{e}}($ Briel, Greger \& Kunzelmann, 1998). Inhibition is not specific to CFTR since coexpression of the chloride channel $(\mathrm{ClC})$ family members $\mathrm{ClC}-0$ and $\mathrm{ClC}-2$ produced similar results (Konig et al., 2001). These authors concluded that the ENaC can be inhibited by any effector/channel that increases $\left[\mathrm{Cl}^{-}\right]_{\mathrm{i}}$ (Konig et al., 2001; Kunzelmann, 2003). In agreement with these results, Xie \& Schafer (2004) demonstrated that ENaC activity may be progressively inhibited by increasing the $\left[\mathrm{Cl}^{-}\right]$in the basolateral solution in the presence of nystatin.

Modulation of glutamate inotropic receptor kainite (GRIK)-type subunits by $\mathrm{Na}^{+}$ and $\mathrm{Cl}^{-}$, is known to stabilize the active dimer conformation (Plested, 2011). Another example of a $\mathrm{Cl}^{-}$-regulated channel is transient receptor potential cation channel subfamily M member 7 (TRPM7), a divalent-selective cation cannel, with a role in regulation of cell growth and proliferation (Yu et al., 2013).

Chloride may have different parallel pathways of signalling, acting either indirectly, through the modulation of kinase cascades [e.g. c-jun N-terminal kinase (JNK) and mitogen activated protein kinase p38 (p38MAPK) that regulate cyclin dependent kinase (CDK) inhibitor p21 (Miyazaki et al., 2008; Ohsawa et al., 2010), or WNKs (Bazua-Valenti et al., 2015; Gagnon et al., 2006a; Moriguchi et al., 2005; Pacheco-Alvarez \& Gamba, 2011; Piala et al., 2014; Yang et al., 2007)], or more directly, by modifying the activity of transcription factors [perhaps runt-related transcription factor 1 (RUNX1) (Backstrom et al., 2002; Wolf-Watz et al., 2001)] or kinases that might regulate the expression or activity of these transcription factors 
(Miyazaki et al., 2008; Ohsawa et al., 2010). In addition, possible parallel effects induced by changes in membrane potential or $\mathrm{Ca}^{2+}$ signalling (Antigny et al., 2011; Nilius et al., 2003; Riazanski et al., 2015), due to $\Delta\left[\mathrm{Cl}^{-}\right]_{\mathrm{i}}$ and vice versa, or effects of $\mathrm{Ca}^{2+}$ signalling on $\left[\mathrm{Cl}^{-}\right]_{\mathrm{i}}(\mathrm{Cabrita}$ et al., 2017; Kunzelmann \& Schreiber, 2014; Kunzelmann et al., 2016; Pokhrel et al., 2011; Schreiber et al., 2015; Sirianant et al., 2016; Tian, Schreiber \& Kunzelmann, 2012; Wanitchakool et al., 2017), may be involved in regulation of $\mathrm{Cl}^{-}$-dependent genes. In this regard, the role of transmembrane member 16 (TMEM16) channels as $\mathrm{Ca}^{2+}$-dependent regulators of $\mathrm{Cl}^{-}$homeostasis is also important (Buchholz et al., 2014; Cabrita et al., 2017; Forschbach et al., 2015; Jin et al., 2016; Juul et al., 2014; Kunzelmann et al., 2009; Kunzelmann et al., 2011a; Kunzelmann, 2015; Kunzelmann et al., 2016; Lerias et al., 2018a; Schreiber \& Kunzelmann, 2016; Sirianant et al., 2016; Wanitchakool et al., 2014). Thus, the crosstalk between $\mathrm{Ca}^{2+}$ and $\mathrm{Cl}^{-}$signalling is significant and quite complex.

\section{(4) Channels as $\mathrm{Cl}^{-}$'sensors'}

Jiang et al. (1998), working on Xenopus laevis oocytes, suggested that the CFTR could respond to changes in $\left[\mathrm{Cl}^{-}\right]_{\mathrm{e}}$ by modulating an ATP efflux pathway, thus acting as a 'chloride sensor'. By mutagenesis of the CFTR, they showed that alterations in residues R347 and R334 of the channel pore might be necessary for activation of ATP efflux in response to increased $\left[\mathrm{Cl}^{-}\right]_{\mathrm{e}}$ (Jiang et al., 1998). Subsequently, Broadbent et al. (Broadbent et al., 2015) found that increased $\left[\mathrm{Cl}^{-}\right]_{\mathrm{e}}$ stimulates CFTR activity, and similarly proposed that CFTR may act as an $\left[\mathrm{Cl}^{-}\right]_{\mathrm{e}}$ sensor (Broadbent et al., 2015). This characteristic was conferred by arginine residue R899, located in extracellular loop 4 of the CFTR, linking $\left[\mathrm{Cl}^{-}\right]_{\mathrm{e}}$ sensing to changes in the ATP binding energy at nucleotide binding domain 1 (NBD1) that affected dimerization with NBD2 and ATP turnover 
(Broadbent et al., 2015). By contrast, Shcheynikov et al. (2015) described the molecular mechanism of $\mathrm{Cl}^{-}$modulation over several electrogenic $\mathrm{Na}^{+} / \mathrm{HCO}_{3}{ }^{-}$transporters as involving a GxxxP motif in $\mathrm{Cl}^{-}$sensing. Amino acid residues from several regions linked to the GxxxP motif become associated to create $\mathrm{Cl}^{-}$-binding sites. These nonchloride transporters were able to sense $\left[\mathrm{Cl}^{-}\right] \mathrm{i}$, suggesting an important role of $\mathrm{Cl}^{-}$in regulating cellular ionic balance (Shcheynikov et al., 2015).

\section{(5) Effects of $\mathrm{Cl}^{-}$on gene expression}

Cyclooxygenase 2 (COX2 or prostaglandin-endoperoxide synthase 2, PTGS2) provides one example of an enzyme whose expression is regulated by $\Delta\left[\mathrm{Cl}^{-}\right]_{\mathrm{i}}$. In studies performed in cortical thick ascending limb of loop of Henle (cTALH) cells from rabbit kidney, increased expression of immuno-reactive COX2 was found when cells were incubated in low- $\mathrm{NaCl}$ medium $\mathrm{NaCl}$ (Cheng et al., 2000). In addition, selective $\mathrm{Cl}^{-}$ substitution induced increased COX2 expression while selective $\mathrm{Na}^{+}$substitution had no effect, suggesting that changes in $\left[\mathrm{Cl}^{-}\right]_{\mathrm{i}}$ may have been responsible for the regulation of COX2 expression (Cheng et al., 2000). A similar result was obtained after incubation in the presence of the NKCC inhibitor bumetanide. Interestingly, incubation of the cells in low-salt or low- $\mathrm{Cl}^{-}$media induced the activation of mitogen activated protein kinase p38 (p38MAPK), JNK and extracellular signal-regulated kinase (ERK). Among these kinases, p38 was primarily responsible for COX2 regulation (Cheng et al., 2000). Similar results regarding COX2 expression and prostaglandin E2 release were obtained by Yang et al. (Yang et al., 2000) using a mouse macula densa cell line. The exact target for $\mathrm{Cl}^{-}$in the regulation of $\mathrm{COX} 2$ expression is still unknown.

(Niisato, Eaton \& Marunaka, 2004) reported osmoregulation of the $\alpha$-subunit messenger RNA (mRNA) of the epithelial $\mathrm{Na}^{+}$channel $(\alpha-\mathrm{ENaC})$ in renal A6 cells (a 
cell line derived from Xenopus laevis distal nephron). Their experimental conditions involved incubation of these cells in hypotonic medium, to decrease $\left[\mathrm{Cl}^{-}\right]_{\mathrm{i}}$. Cytosolic $\left[\mathrm{Cl}^{-}\right]$was modulated in different ways: by activating or blocking the NKCC with the flavone apigenin and bumetanide, respectively, and by blocking $\mathrm{Cl}^{-}$channels using 5nitro-2-(phenylpropylamino)-benzoic acid (NPPB) (Niisato et al., 2004). It was observed that low $\left[\mathrm{Cl}^{-}\right]_{\mathrm{i}}$ caused increased $\alpha-\mathrm{ENaC}$ expression and increased $\mathrm{Na}^{+}$ reabsorption. The same authors later observed that $\left[\mathrm{Cl}^{-}\right]_{\mathrm{i}}$ reduction caused by incubation in hypotonic medium also led to increased expression of the $\beta$ and $\gamma$-subunits of the ENaC (Niisato et al., 2007). Increased expression of the $\beta$ and $\gamma$-subunits was mediated through the p38 mitogen-activated protein kinase (MAPK), while the $\alpha$-subunit was not modulated by this pathway (Niisato et al., 2007). These results suggest that changes in $\left[\mathrm{Cl}^{-}\right]_{\mathrm{i}}$, in this case induced by incubating cells in hypotonic media, might regulate several signalling pathways, with consequences for gene regulation. However, the specific mechanisms by which $\mathrm{Cl}^{-}$regulated the expression of these subunits remain unclear. They may include direct $\mathrm{Cl}^{-}$effects, acting as a second messenger for certain $\mathrm{Cl}^{-}$-sensor proteins or transcription factors, or indirect $\mathrm{Cl}^{-}$effects resulting from the incubation in hypotonic media, or the presence of impermeable ions (gluconate, isethionate, $\mathrm{N}$-methyl-D-glucamine, choline, etc.), which may result in changes in plasma transmembrane potential, cell volume, or other general effects.

Succol et al. (Succol et al., 2012), in an interesting study involving the GABA type A receptor subunits (GABAA receptor/GABA AR/GABR/GABA-gated chloride channel subunits) in mouse primary cerebellar neurons, used electrophysiological and immunocytochemical methods to show that $\left[\mathrm{Cl}^{-}\right]_{\mathrm{i}}$ regulates expression of the $\alpha 3-1$ and $\delta$ subunits of this receptor and $\mathrm{Cl}^{-}$channel. Over-expression of potassium chloride cotransporter 2 (KCC2) or treatment with bumetanide, a pharmacological inhibitor of 
the NKCC1, were used to alter $\left[\mathrm{Cl}^{-}\right] \mathrm{i}$. To increase $\left[\mathrm{Cl}^{-}\right] \mathrm{i}$, mature neurons were transfected with KCC2 short hairpin RNA (shRNA) or chronically treated with the KCC2 inhibitor R-(+)-[(dihydroindenyl)oxy]alkanoic acid (DIOA) without affecting the expression level of $\mathrm{KCC} 2$. The results suggest that changes in the $\left[\mathrm{Cl}^{-}\right]_{\mathrm{i}}$ were responsible for regulation of the $\alpha 3-1$ and $\delta$ subunits of the GABAA receptor. Although the mRNA expression levels of these subunits were not measured, the differential protein expression and composition of these GABAA receptor subtypes could involve transcriptional regulation. Therefore, it would be of interest to determine if $\left[\mathrm{Cl}^{-}\right]_{\mathrm{i}}$ changes in neurons affect the GABAA receptor at the transcriptional or translational level, and to find the mechanism of signal transduction for $\mathrm{Cl}^{-}$. The GABAA receptor is known to be involved in developmental regulation (Laurie, Wisden \& Seeburg, 1992).

Taken together, these results a physiological role of $\left[\mathrm{Cl}^{-}\right]_{\mathrm{i}}$ in the modulation of GABAergic inhibition, and support a role for $\mathrm{Cl}^{-}$as a intracellular signal controlling GABAA receptor function (Succol et al., 2012).

In recent experiments, using differential display and incubating cells in different $\left[\mathrm{Cl}^{-}\right.$ ] in the presence of nigericin and tributyltin, we observed several differentially expressed gene products, and identified two of these as glutaredoxin 5 (GLRX5) and ribosomal protein S27 (RPS27) (Valdivieso et al., 2016). Although the mechanisms of regulation of these genes by $\mathrm{Cl}^{-}$are not yet clear, these results demonstrate the existence of a number of $\mathrm{Cl}^{-}$-dependent genes, that could be directly or indirectly modulated by $\mathrm{Cl}^{-}$. Examples of known $\mathrm{Cl}^{-}$-dependent genes and proteins are provided in Table 2.

\section{(6) Effects of $\mathrm{Cl}^{-}$on transcription factors}

One group of proteins potentially able to sense changes in $\left[\mathrm{Cl}^{-}\right]_{\mathrm{i}}$ is the transcription factors (TFs). However, the only report of a TF responding to changes in 
$\left[\mathrm{Cl}^{-}\right]$is for RUNX1 (Backstrom et al., 2002). The nuclear magnetic resonance (NMR) structure of RUNX1 [also named acute myeloid leukemia-1 (AML-1a)] showed that two $\mathrm{Cl}^{-}$anions are associated with this protein (Wolf-Watz et al., 2001). Interestingly, in a later study, it was found that binding of RUNX1 to DNA was modulated in a $\mathrm{Cl}^{-}$dependent manner (Backstrom et al., 2002), suggesting that RUNX1 could regulate the expression of some $\mathrm{Cl}^{-}$-dependent genes. However, a direct effect of $\mathrm{Cl}^{-}$on $\mathrm{RUNX1-}$ dependent genes has not yet been demonstrated. Nevertheless, these data suggest that $\mathrm{Cl}^{-}$, in addition to other cytoplasmic effects, might directly modulate the transcriptional activity of some TFs. The possible existence of a $\mathrm{Cl}^{-}$-modulated TF family is an interesting area yet to be explored, and perhaps could open new frontiers of research for the study of diseases involving $\mathrm{Cl}^{-}$homeostasis.

\section{CELLULAR PROCESSES REGULATED BY INTRACELLULAR CHLORIDE CHANGES}

The regulation of several cellular processes has been associated with changes in $\left[\mathrm{Cl}^{-}\right]_{\mathrm{i}}$, modulated by $\mathrm{Cl}^{-}$channels and transporters (Duran et al., 2010). This function of $\mathrm{Cl}^{-}$as a second messenger (Orlov \& Hamet, 2006; Valdivieso et al., 2016) could be of great importance in diverse pathologies where $\left[\mathrm{Cl}^{-}\right]_{\mathrm{i}}$ is altered. In this section, we consider the effects of $\left[\mathrm{Cl}^{-}\right]_{i}$ changes in regulating different cellular processes.

\section{(1) Cytoskeletal dynamics}

Nunes et al. (Nunes et al., 2015) showed that the ionic imbalance produced in cells challenged with high $\left[\mathrm{Cl}^{-}\right]_{\mathrm{i}}$ affected cytoskeletal dynamics, vesicle motility, and mitochondrial function. These effects were seen following isovolumetric elevation of $\left[\mathrm{Cl}^{-}\right]_{\mathrm{i}}$, using the double-ionophore strategy (nigericin and tributyltin) (Krapf et al., 1988; 
Valdivieso et al., 2016). Cells responded to small increases in $\left[\mathrm{Cl}^{-}\right]_{\mathrm{i}}$ independently of the molecular crowding that occurs due to the shrinkage of cells during their adaptation to high osmolality (Nunes et al., 2015). Thus, $\left[\mathrm{Cl}^{-}\right]_{\mathrm{i}}$ changes might represent the initial events in adaptation to environmental changes, modifying some enzymatic activities in response to extracellular hypertonicity.

\section{(2) Cell cycle and proliferation}

Chloride channels, and therefore $\mathrm{Cl}^{-}$, play important roles in the regulation of cell cycle progression and proliferation (Hiraoka et al., 2010; Klausen et al., 2010; Nakajima \& Marunaka, 2016). Lai et al. (Lai et al., 2003) investigated the role of $\left[\mathrm{Cl}^{-}\right]_{\mathrm{i}}$ in the activation and proliferation of Jurkat leukemic T-lymphocyte cells. Treatment of these cells with phytohemagglutinin or concanavalin A led to increased $\left[\mathrm{Cl}^{-}\right]_{\mathrm{i}}$ accompanied by $\mathrm{Cl}^{-}$oscillations (Lai et al., 2003). Lectin-induced $\left[\mathrm{Cl}^{-}\right]_{\mathrm{i}}$ increase was blocked by removal of extracellular $\mathrm{Cl}^{-}$or by using an inhibitor of $\mathrm{Cl}^{-}$channels (anthracene-9 carboxylate), which also inhibited Jurkat cell proliferation. These results suggested, for the first time, that $\left[\mathrm{Cl}^{-}\right]_{\mathrm{i}}$ oscillations, like $\mathrm{Ca}^{2+}$ oscillations, could play a role in cell proliferation (Lai et al., 2003).

$\left[\mathrm{Cl}^{-}\right]_{\mathrm{i}}$ may modulate the $\mathrm{G} 1 / \mathrm{S}$ cell-cycle checkpoint by regulating the expression of p21 (Miyazaki et al., 2008; Ohsawa et al., 2010). Low $\left[\mathrm{Cl}^{-}\right]_{\mathrm{i}}$ was associated with reduced cell growth characterized by an arrested G1 to S phase in MKN28 cells (a human gastric cancer cell line). The process involved increased expression of $\mathrm{p} 21$, which is a cyclin-dependent kinase (CDK) inhibitor (Miyazaki et al., 2008). p21 upregulation caused by low $\left[\mathrm{Cl}^{-}\right]_{\mathrm{i}}$ was independent of $\mathrm{p} 53$, which is a common transactivator of p21 (Miyazaki et al., 2008). However, p21 upregulation was mediated by MAPKs, since the inhibitors SB202190 (inhibitor of p38) and SP600125 (inhibitor 
of JNK) abolished p21 overexpression and normalized cell proliferation (Ohsawa et al., 2010). The ERK-kinase inhibitor FR180204 did not affect p21 expression or proliferation.

Nakajima \& Marunaka (2016) identified a role of $\left[\mathrm{Cl}^{-}\right]_{\mathrm{i}}$ in growing neurites of PC12 cells. Detecting $\mathrm{Cl}^{-}$using the fluorescent probe 1-(Ethoxycarbonylmethyl)-6methoxyquinolinium bromide (MQAE), they found higher $\left[\mathrm{Cl}^{-}\right]_{\mathrm{i}}$ in the tip of the outgrowing neurite compared to the cell body. A positive correlation was found between $\left[\mathrm{Cl}^{-}\right]_{\mathrm{i}}$ and the length of growing neurites. Using bumetanide to inhibit NKCC1 led to decreases in $\left[\mathrm{Cl}^{-}\right]_{\mathrm{i}}$ and neurite outgrowth. These results suggest that high $\left[\mathrm{Cl}^{-}\right]_{\mathrm{i}}$ is important for efficient neurite outgrowth. It should be noted that the use of a medium with a low $\left[\mathrm{Cl}^{-}\right]_{\mathrm{e}}$ (replacing $\mathrm{Cl}^{-}$with $\mathrm{NO}_{3}^{-}$) in these experiments might have had both direct effects on p38 and JNK modifier kinases, and indirect effects due to changes in plasma membrane potential, cell volume, molecular crowding, intracellular $\mathrm{pH}$, etc. Further studies are needed to understand these very interesting observations better. Klausen et al. (Klausen et al., 2010) reported a role of monovalent ions in the control of proliferation in Ehrlich-Lettre Ascites (ELA) tumour cells. Through monovalent ion-substitution experiments using impermeable anions, it was found that $\mathrm{Cl}^{-}$substitution strongly inhibited proliferation and increased intracellular $\mathrm{Ca}^{2+}$ concentration $\left(\left[\mathrm{Ca}^{2+}\right]_{i}\right)$. The authors suggested that $\mathrm{Cl}^{-}$might regulate proliferation by fine-tuning the transmembrane potential $\left(E_{\mathrm{m}}\right)$ in the $\mathrm{S}$ phase and modifying $\mathrm{Ca}^{2+}$ signalling. They also showed that $\mathrm{Na}^{+}$may modulate ELA cell proliferation by regulating intracellular $\mathrm{pH}\left(\mathrm{pH}_{\mathrm{i}}\right)$, with a much stronger effect than $\mathrm{Cl}^{-}$itself (Klausen $e t$ al., 2010). They suggested that $\mathrm{Na}^{+}$and $\mathrm{Cl}^{-}$act via different mechanisms to regulate proliferation, proposing 'anion permeability' rather than $\left[\mathrm{Cl}^{-}\right]$as the event that regulates proliferation via changes in $E_{\mathrm{m}}$ (Klausen et al., 2010). In contrast with the work of 
(Miyazaki et al., 2008; Ohsawa et al., 2010), Klausen et al. (Klausen et al., 2010) suggested that $\mathrm{Cl}^{-}$does not function as a messenger since its concentration did not change between the G1 and S phases. It is likely that several mechanisms are simultaneously in operation when $\left[\mathrm{Cl}^{-}\right]_{\mathrm{i}}$ changes: direct and specific $\mathrm{Cl}^{-}$effects, changes in membrane potential and changes in $\mathrm{Ca}^{2+}$ and other second messengers and signalling pathways. The $\mathrm{Ca}^{2+}$-activated $\mathrm{Cl}^{-}$channel (CaCC) TMEM16A/ANO1/TAOS2/DOG1 is known to induce ERK1/2 and cyclin D1, contributing to tumorigenesis and cancer progression (Duvvuri et al., 2012). Pharmacological inhibition of mitogen-activated protein kinase kinase MEK/ERK signalling pathway or genetic inactivation of ERK resulted in the opposite effect, abrogating cell proliferation (Duvvuri et al., 2012). In addition, when a hypomorphic mutant of TMEM16A is expressed, ERK is not activated. Other reports suggest that CaCCs can both promote and retard cell proliferation (Lerias et al., 2018b; Spitzner et al., 2008), with the reasons behind these contradictory results still unknown. TMEM16A is also a key factor in the activity of the $\mathrm{Cl}^{-}$channel CFTR (Kunzelmann et al., 2012; Ousingsawat et al., 2011; Wanitchakool et al., 2016). Interestingly, TMEM16A also has effects on endosomal $\mathrm{pH}$ acidification and renal proximal protein reabsorption; TMEM16A currents were activated by acidic $\mathrm{pH}$ (Faria et al., 2014). CFTR failure induces reduced extracellular $\mathrm{pH}$ in cultured epithelial cells due to the overexpression and increased activity of lactate dehydrogenase (LDH), partially through SRC proto-oncogene, non-receptor tyrosine kinase (c-Src) and JNK signalling (Massip-Copiz \& Santa-Coloma, 2018; Valdivieso et al., 2019).

\section{(3) Changes in intracellular $\mathrm{Cl}^{-}$and apoptosis}

An important initial event during apoptosis is cell shrinkage, which is mediated by the activation of ion channels that release $\mathrm{K}^{+}, \mathrm{Cl}^{-}$and organic molecules that drive 
water out of the cells by osmotic pressure (Kunzelmann, 2016; Wanitchakool et al., 2016). In $\mathrm{Cl}^{-}$extrusion, leucine-rich repeat-containing 8 (LRRC8), TMEM16/anoctamin and CFTR $\mathrm{Cl}^{-}$channels are particularly important (Wanitchakool et al., 2016).

In Jurkat T-cells, a specific effect of $\left[\mathrm{Cl}^{-}\right]_{\mathrm{i}}$ has been identified in the regulation of apoptosis, impairing the intrinsic but not the extrinsic apoptotic pathway through signalling upstream of mitochondria (JNK signalling) (Heimlich \& Cidlowski, 2006). Modulation of the $\left[\mathrm{Cl}^{-}\right]_{\mathrm{i}}$ was achieved using the non-specific anion channel inhibitor disodium 4-acetamido-4'-isothiocyanato-stilben-2,2'-disulfonate (SITS), to increase $\left[\mathrm{Cl}^{-}\right.$ ]$_{\mathrm{i}}$, and the Roswell Park Memorial Institute (RPMI) culture medium with reduced $\left[\mathrm{Cl}^{-}\right]_{\mathrm{e}}$, to reduce $\left[\mathrm{Cl}^{-}\right]_{\mathrm{i}}$. The effects of SITS and low-Cl- $\mathrm{RPMI}$ on $\left[\mathrm{Cl}^{-}\right]_{\mathrm{i}}$ were visualized by using 6-Methoxy-N-ethylquinolinium iodide (MEQ) fluorescence. Ultraviolet-C (UVC) exposure reduced the $\left[\mathrm{Cl}^{-}\right]_{i}$ and induced apoptosis through activation of JNK, an effect inhibited in the presence of SITS or by reducing $\left[\mathrm{Cl}^{-}\right]_{\mathrm{e}}($ Heimlich \& Cidlowski, 2006). It was not clear how reduced $\left[\mathrm{Cl}^{-}\right]_{\mathrm{i}}$ could have the same effect as increased $\left[\mathrm{Cl}^{-}\right]_{\mathrm{i}}$. It is possible that $\mathrm{JNK}$ has a biphasic response to $\mathrm{Cl}^{-}$, with maximal activity at intermediate $\left[\mathrm{Cl}^{-}\right]$- a pattern known for interleukin-1 $\beta(\mathrm{IL}-1 \beta)$, which also has a biphasic response to $\mathrm{Cl}^{-}$(Clauzure et al., 2017).

The TMEM16/anoctamin channels have effects on several cell death pathways (Hammer et al., 2015; Ousingsawat et al., 2015; Simoes et al., 2018; Skals et al., 2010; Skeggs et al., 1954; Wanitchakool et al., 2016; Wanitchakool et al., 2017). However, the role of $\mathrm{Cl}^{-}$itself in these apoptotic processes is largely unknown. Beyond its osmotic effect on cell shrinkage, $\mathrm{Cl}^{-}$may have a specific intracellular signalling role during the apoptotic process. The mechanisms by which changes in $\left[\mathrm{Cl}^{-}\right]_{\mathrm{i}}$ affect apoptosis and the downstream effects of $\mathrm{Cl}^{-}$still require investigation.

\section{(4) Effects of $\mathrm{Cl}^{-}$on intracellular organelles}


Miller et al. (Miller et al., 2007) showed that, in response to IL-1 $\beta$ and tumour necrosis factor (TNF), NADPH oxidase (NOX1) generates reactive oxygen species (ROS) in early endosomes, and this is potentiated by activity of the ClC-3 channel. They postulated that $\mathrm{ClC}-3$-dependent $\mathrm{Cl}^{-}$transport in these endosomes was required to equilibrate the charges of electron flow generated by NOX1, maximizing ROS generation and nuclear factor kappa B (NF-kB) activation (Miller et al., 2007). More recently, the same laboratory reported that activation of swelling-activated chloride current $\left(\mathrm{ICl}_{\text {swell }}\right)$ by TNF requires $\mathrm{ClC}$-3-dependent endosomal ROS production and that LRRC8A, a required component of volume-regulated anion channels (VRACs), is involved in TNF-induced superoxide production by NOX1 (Choi et al., 2016). It is evident that the signalling mechanisms of TNF and IL-1 $\beta$ are quite complex.

A similar mechanism of charge neutralization has been postulated for the $\mathrm{Ca}^{2+}$ channel TRPC6 and the chloride channel CFTR, allowing $\mathrm{pH}$ reduction in phagosomes (Riazanski et al., 2015). Painter et al. (Painter et al., 2010) reported a role of $\mathrm{Cl}^{-}$in the phagosome of human neutrophils as a substrate for hypochlorite $(\mathrm{HOCl})$ production, catalysed by myeloperoxidase (MPO). They suggested that CFTR activity is involved in halide transport into the phagosome lumen. Thus, the intracellular and intraorganellar $\mathrm{Cl}^{-}$concentration could play a role in host defence against infection, underlining the importance of $\mathrm{Cl}^{-}$homeostasis and its effects as second messenger on innate immunity. Antigny et al. (Antigny et al., 2011) showed that TRPC6 links $\mathrm{Ca}^{2+}$ mishandling in cystic fibrosis to CFTR channel dysfunction, and that both channels are functionally and reciprocally coupled within a molecular complex in the phagosomes of airway epithelial cells.

Nunes et al. (Nunes et al., 2015) reported direct effects of $\mathrm{Cl}^{-}$on mitochondrial membrane potential and ATP production. Recent work has shown that IL-1 $\beta$, which is 
also produced by a $\mathrm{Cl}^{-}$-dependent gene, is involved in the reduction of mitochondrial Complex I and increased ROS activity in cells with impaired CFTR activity, cells that have an increased $\left[\mathrm{Cl}^{-}\right]_{\mathrm{i}}$ since their anion extrusion is affected (Clauzure et al., 2014; Clauzure et al., 2017; Massip-Copiz et al., 2017; Valdivieso et al., 2012; Valdivieso \& Santa-Coloma, 2013).

\section{(5) Effects of $\mathrm{Cl}^{-}$on inflammation and immunity}

(Shapiro \& Dinarello, 1997) made the interesting observation that a hyperosmotic stress stimulates proinflammatory cytokine production. Using hyperosmotic $\mathrm{NaCl}$ stress in human peripheral blood mononuclear cells (PBMCs) in vitro, they showed that $\mathrm{NaCl}$ induced increased mRNA levels for IL-1 $\alpha$ and IL-1 $\beta$. These mRNA levels increased by 50- and sevenfold over controls, respectively, but were poorly translated into protein. The addition of femtomolar concentrations of bacterial lipopolysaccharide, IL-1 $\alpha$, or $1 \%$ normal human serum resulted in the synergistic protein synthesis of IL- $1 \alpha$, IL-1 $\beta$, TNF, and IL-8. Similarly, Tabary et al. (Tabary et al., 2000) reported that primary human CF bronchial gland cells exhibit abnormally high IL-8 production through constitutively activated NF- $\mathrm{kB}$ (nuclear factor kappa-light-chain-enhancer of activated $\mathrm{B}$ cells) and high I $\mathrm{B} \alpha$ (nuclear factor of kappa light polypeptide gene enhancer in Bcells inhibitor, alpha) kinase levels. In CF gland cells, compared with high IL-8 levels present in a hypertonic solution, the release of IL-8 was significantly reduced by twofold in an isotonic solution and fivefold in a hypotonic solution. Intriguingly, this reduced expression was not accompanied by inhibition of the activated NF- $\kappa \mathrm{B}$. Chan $e t$ al. (Chan, Chmura \& Chan, 2006), using IB3-1 epithelial CF cells, also showed increased constitutive IL- 8 secretion in response to $\mathrm{NaCl}$ compared to $\mathrm{CF}$-corrected $\mathrm{C} 38$ cells, and that this effect was not entirely due to osmolarity, since sorbitol had less 
impact than $\mathrm{NaCl}$. These studies clearly demonstrate a proinflammatory effect of $\mathrm{NaCl}$ although the specific effects of $\mathrm{Cl}^{-}$or $\mathrm{Na}^{+}$were not addressed. However, they agree with recent observations that $\mathrm{Cl}^{-}$by itself can induce IL- $1 \beta$ secretion and autocrine signalling (Clauzure et al., 2017), and with previous studies showing that mutant CFTR accumulates in the ER, leading to ER stress and $\mathrm{Ca}^{2+}$ release, with $\Delta \mathrm{F} 508$ (deletion of phenylalanine 508)-CFTR as a $\mathrm{Cl}^{-}$counter-ion channel, culminating in IL-8 release (Barro Soria et al., 2009; Martins et al., 2011). Counter-ion effects of $\mathrm{Cl}^{-}$were originally observed for $\mathrm{ER} \mathrm{Ca}^{2+}$ release from skeletal muscle (Fink \& Veigel, 1996), and more recently in endosomes during the activation of NOX1 through the chloride channel CLC-3 (Miller et al., 2007), and in the activation of the TRPC6 $\mathrm{Ca}^{2+}$ channel (Riazanski et al., 2015), where $\mathrm{Cl}^{-}$, through the CFTR channel, shunts the transmembrane potential generated by movement of protons. LRRC8A has a similar effect in TNF $\alpha$ signalling (Choi et al., 2016).

Maldonado et al. (Maldonado et al., 1991) reported evidence for the activation of $\mathrm{Cl}^{-}$currents induced by prostaglandin $\mathrm{E}_{1}\left(\mathrm{PGE}_{1}\right)$ via a protein kinase $\mathrm{A}$ (PKA)dependent pathway in Jurkat T cells. This $\mathrm{Cl}^{-}$current activated by cyclic AMP (cAMP) could involve CFTR activity, since this channel is activated by PKA (Anderson et al., 1991). Given that prostaglandins are involved in immunosuppression and inhibition of proliferative responses in T lymphocytes, as is known for $\mathrm{PGE}_{2}$ (Makoul et al., 1985), it is possible that there is a link between $\left[\mathrm{Cl}^{-}\right]_{\mathrm{i}}$ changes and the proliferation of these cells. This interesting issue should be explored in the future.

A possible role of $\mathrm{Cl}^{-}$as a second messenger in inflammation and immunity was postulated by Menegazzi et al. (Menegazzi et al., 2000), who reported the activation of $\beta_{2}$ integrins in neutrophilic polymorphonuclear leukocytes (PMNs) triggered by TNF and induced by $\mathrm{Cl}^{-}$. It was suggested that TNF regulates the functional activity of 
neutrophil $\beta 2$ integrins through modulation of conformational changes that depend on $\left[\mathrm{Cl}^{-}\right]_{\mathrm{i}}$. A drop in $\left[\mathrm{Cl}^{-}\right]_{\mathrm{i}}$ was necessary for TNF-induced $\beta 2$ integrin activation (Menegazzi et al., 2000). Lai et al. (Lai et al., 2003) using human Jurkat T lymphocytes as cellular model, showed increased $\left[\mathrm{Cl}^{-}\right]_{\mathrm{i}}$ in lectin-activated Jurkat cells. The lectininduced proliferation was blocked in the presence of a $\mathrm{Cl}^{-}$transporter inhibitor, anthracene-9-carboxylate (9-AC) or in $\mathrm{Cl}^{-}$-free conditions when $\mathrm{Cl}^{-}$was replaced with gluconate (Lai et al., 2003). These results show the significance of $\mathrm{Cl}^{-}$in the regulation of T cells, perhaps acting as a second messenger for T-cell receptors (TCRs).

Interestingly, the ClC-3 chloride channel, which is involved in $\mathrm{Cl}^{-}$efflux regulation (Zhou et al., 2005), has been also reported as a regulator of NF- $\mathrm{BB}$ signalling in aortic smooth muscle cells (Miller et al., 2007). Conversely, the chloride current of ClC-3 was activated by the cytokines TNF and IL-1 $\beta$ (Matsuda et al., 2010; Miller et al., 2007). Yang et al. (Yang et al., 2012) explored the link between the $\mathrm{ClC}-3,\left[\mathrm{Cl}^{-}\right]_{\mathrm{i}}$ and the proinflammatory responses mediated by TNF, suggesting that intracellular $\mathrm{Cl}^{-}$ behaves as a second messenger for the $\mathrm{ClC}-3$ channel. In human umbilical vein endothelial cells (HUVECs), incubated at low $\mathrm{Cl}^{-}$concentration by replacing extracellular $\mathrm{Cl}^{-}$with gluconate, they observed enhanced activation of NF- $\kappa \mathrm{B}$ in response to TNF stimulation. ClC-3 knockdown cells, obtained by using small interfering RNA, also showed a decreased TNF-activated $\mathrm{Cl}^{-}$current and NF- $\mathrm{BB}$ response. Treatments with IL-1 $\beta$ or angiotensin II produced similar results to those obtained with TNF (Yang et al., 2012).

\section{V. $\mathrm{Cl}^{-}$AS A SIGNALLING EFFECTOR FOR CFTR}

Another well-studied chloride channel is the CFTR, responsible for the disease cystic fibrosis (CF) (Frizzell, 1999; Kerem et al., 1989; Riordan et al., 1989; Rommens 
et al., 1989). The channel is activated by cAMP through PKA phosphorylation and ATP binding (Anderson et al., 1991; Berger, Travis \& Welsh, 1993; Chang et al., 2002;

Riordan, 2008; Rommens et al., 1991; Seavilleklein et al., 2008). PKC (Seavilleklein et al., 2008), c-Src (Fischer \& Machen, 1996) and WNK kinases (Yang et al., 2007) also modulate its activity (WNK1 and WNK4 are inhibitory). The 3D structure of the CFTR has recently been reported (Liu et al., 2017).

After the CFTR was cloned by Riordan et al. (Riordan et al., 1989), most studies attempting to explain the CF phenotype focused on the non-genomic and extracellular effects of CFTR. However, the phenotype was too complex to be explained only by failure of $\mathrm{Cl}^{-}$transport and the accompanying $\mathrm{Na}^{+}$and water permeation. Thus, we hypothesized that the complex $\mathrm{CF}$ phenotype might be the result of the expression of a net of CFTR-dependent genes, modulated by the activity of the CFTR channel $\left(\mathrm{Cl}^{-}\right.$ transport). To prove this hypothesis, we applied the differential display method to cultured cells. Initially, human blood lymphocytes derived from a CF family were used, but the results were inconsistent. To increase reproducibility, we decided to use cultured cells. As a first approach, we used T84 coloncarcinoma cells treated with 12-Otetradecanoylphorbol (TPA), since TPA negatively regulates CFTR expression and thus might emulate a CF phenotype. In this way we identified the phorbol ester induced gene 1 (PEIG1) as a TPA-dependent gene (now called GPRC5A) (Cafferata et al., 1995; Cafferata et al., 1996). [Also by using differential display, this gene was later rediscovered as a retinoic acid induced gene (Cheng \& Lotan, 1998)]. By testing different possible modulators of the CFTR, we also found that IL-1 $\beta$ modulated CFTR expression in a biphasic way, through NF-kB (Cafferata et al., 2000; Cafferata et al., 2001; Cafferata et al., 1997). To improve the model system, we then applied the differential display method to find differences in the genes expressed by CFDE cells 
(CF cells) and their CFTR-corrected counterparts, the latter also treated or not with CFTR inhibitors. The use of the CFTR inhibitor NPPB in the CFTR corrected CFDE cells (called "CFDE/6Rep-CFTR cells") allowed us to identify functional differences due only to the $\mathrm{Cl}^{-}$transport activity of the CFTR - we selected the differential display spots in which the signal reverted to control values in the presence of NPPB - avoiding possible off-target effects of wild-type CFTR-transfected cells or effects exclusively due to the presence of the CFTR on the plasma membrane, as seems to be the case for RANTES (regulated upon activation, normally T-expressed, and presumably secreted) (Estell et al., 2003) and other PDZ ( PSD-95(postsynaptic density protein 95 )/Discs large/ZO-1(zona occludens protein-1) homologous)-dependent genes (Boucherot, Schreiber \& Kunzelmann, 2001; Sharma et al., 2016; Watson et al., 2016). In this way, we found and characterized several CFTR-dependent genes, including c-Src (GonzalezGuerrico et al., 2002), mitochondrially encoded NADH:ubiquinone oxidoreductase core subunit 4 (MTND4) (Valdivieso et al., 2007) and CDGSH Iron Sulfur Domain 1 (CISD1) (Taminelli et al., 2008). Other laboratories, using microarrays, also found CFTR-dependent genes, although without further characterization (Galvin et al., 2004; Srivastava, Eidelman \& Pollard, 1999; Xu et al., 2003). Thus, the existence of CFTRdependent genes was demonstrated.

c-Src was the first signalling element identified in the CFTR signalling pathway. We hypothesized that changes in $\left[\mathrm{Cl}^{-}\right]_{\mathrm{i}}$ could be the first step in the CFTR 'signalling mechanism', with a role for $\mathrm{Cl}^{-}$as a signalling effector or 'second messenger' in the modulation of specific genes. The term 'second messenger' for $\mathrm{Cl}^{-}$was chosen by analogy to the $\mathrm{Ca}^{2+}$ signalling of ligand-gated ion channels (Mahaut-Smith, Taylor \& Evans, 2016) as proposed by other authors (Bekar \& Walz, 1999; Duran et al., 2010; Menegazzi et al., 2000; Orlov \& Hamet, 2006; Succol et al., 2012). However, although 
the CFTR can be considered operationally as a ligand-gated channel (Chen \& Hwang, 2008), the $\mathrm{Cl}^{-}$transported by CFTR may also have extracellular effects; therefore, the expression ' $\mathrm{Cl}^{-}$as a signalling effector', used herein seems more appropriate to describe the general effects of $\mathrm{Cl}^{-}$, including intracellular functions as a second messenger for CFTR and other channels.

To demonstrate the hypothesis of $\mathrm{Cl}^{-}$acting as a signalling effector for CFTR, we again used the differential display method to analyse the mRNA expression pattern of IB3-1 cells, an immortalized human tracheobronchial epithelial cell line derived from a CF patient. These cells were incubated at different $\mathrm{Cl}^{-}$concentrations by using a double ionophore strategy (Valdivieso et al., 2015) first developed to measure $\left[\mathrm{Cl}^{-}\right]_{\mathrm{i}}(\mathrm{Krapf}$ et $a l ., 1988)$. It uses the ionophores nigericin and tributyltin to equilibrate the $\left[\mathrm{Cl}^{-}\right]_{\mathrm{i}}$ and $\left[\mathrm{Cl}^{-}\right]_{\mathrm{e}}$. This strategy of fixing the $\left[\mathrm{Cl}^{-}\right]_{\mathrm{i}}$ allowed us to investigate changes in gene expression caused specifically by $\mathrm{Cl}^{-}$and not by the changes in membrane potential, cell volume or molecular crowding that may result from incubations using hypo- or hypertonic media, or when replacing the extracellular $\mathrm{Cl}^{-}$with another anion such as glutamate. It has been shown previously that these ionophores clamp the $\mathrm{pH}$ and the cell volume while $\left[\mathrm{Cl}^{-}\right]$is changed (Krapf et al., 1988; Nunes et al., 2015). Although direct proof is still lacking, these ionophores should not affect the membrane potential since they are not electrogenic (Antonenko \& Bulychev, 1991; Pohl et al., 1997). Using this strategy, we found several differentially expressed mRNAs and characterized two of these, corresponding to RPS27 and GLRX5 (Valdivieso et al., 2016). We also demonstrated that $I L-1 \beta$ is a $\mathrm{Cl}^{-}$-dependent gene (Clauzure et al., 2017; Massip-Copiz et $a l .$, 2018). Our results demonstrated the existence of numerous $\mathrm{Cl}^{-}$-dependent genes, and that changes in $\left[\mathrm{Cl}^{-}\right]_{\mathrm{i}}$ could, directly or indirectly, modulate the expression of specific genes in mammalian cells. Our use of nigericin and tributyltin allowed us to 
attribute the response of these genes specifically to $\mathrm{Cl}^{-}$rather than to indirect changes in cell volume, membrane potential or $\mathrm{pH}$. In addition, we recently demonstrated that inhibition of CFTR activity in T84 cells can cause RPS27 modulation by CFTR due to the consequent $\mathrm{Cl}^{-}$accumulation (Valdivieso et al., 2017). Therefore, $\mathrm{Cl}^{-}$is clearly acting as a second messenger for CFTR. Nevertheless, some of the observed changes may be due to secondary transport processes such as those involving $\mathrm{Na}^{+}, \mathrm{K}^{+}$and $\mathrm{Ca}^{2+}$ under $\mathrm{Cl}^{-}$modulation, and therefore our results in the presence of ionophores must be interpreted with caution.

We have recently identified additional steps in CFTR signalling mechanisms that involve $\mathrm{Cl}^{-}$(Valdivieso et al., 2016; Valdivieso et al., 2017), IL-1 $\beta$ (Clauzure et al., 2017; Massip-Copiz et al., 2018; Massip-Copiz et al., 2017) and c-Src (Massip-Copiz et al., 2018; Massip-Copiz et al., 2017), which may explain the reduced mitochondrial Complex I activity (Clauzure et al., 2014; Valdivieso, 2009; Valdivieso et al., 2012) and increased ROS levels found in cultured CF cells (Clauzure et al., 2014; Clauzure et al., 2017; Massip-Copiz et al., 2018; Massip Copiz \& Santa Coloma, 2016). $\mathrm{Cl}^{-}$modulates IL-1 $\beta$ mRNA and protein expression in a biphasic way, with maximal expression at 75 $\mathrm{mM}\left[\mathrm{Cl}^{-}\right]_{\mathrm{i}}$ in the presence of nigericin and tributyltin (Clauzure et al., 2017). We postulate that this is the result of two steps: (1) $\Delta\left[\mathrm{Cl}^{-}\right]_{\mathrm{i}}$ modulates IL-1 $\beta$ secretion; (2) the secreted IL- $1 \beta$ initiates an autocrine positive-feedback loop, increasing its own mRNA levels and the synthesis of immature pro-IL-1 $\beta$, which in turn is cleaved and secreted to start a new cycle of IL-1R stimulation, resulting in signal amplification. Thus, the effects of $\mathrm{Cl}^{-}$on IL-1 $\beta$ expression appear to be indirect, increasing the amount of secreted IL-1 $\beta$ which in turn stimulates its own gene expression. The mechanism by which $\left[\mathrm{Cl}^{-}\right]_{\mathrm{i}}$ modulates IL-1 $\beta$ secretion is unknown. However, a recent study reports a possible central role of SGK1 as a $\mathrm{Cl}^{-}$-dependent kinase, which might be involved in 
NLRP3 (nucleotide-binding oligomerization domain-like receptor family, pyrin domain containing 3) inflammasome activation through NF-אB (Zhang et al., 2018).

Using the double-ionophore strategy, we observed that increased $\left[\mathrm{Cl}^{-}\right]$modulates IL-1 $\beta$ in a biphasic way, with maximal IL- $1 \beta$ expression and secretion at $75 \mathrm{mM}$ (Clauzure et al., 2017). However, other authors (Hiraoka et al., 2010; Miyazaki et al., 2008; Ohsawa et al., 2010) found a reduction of extracellular $\mathrm{Cl}^{-}$-induced p38 and JNK

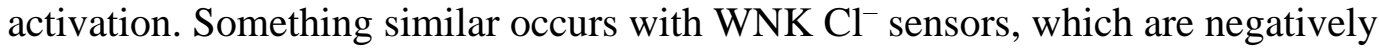
modulated by increased $\left[\mathrm{Cl}^{-}\right]$(Sun et al., 2018). However, SGK1 showed a response to $\mathrm{Cl}^{-}$similar to that seen for IL-1 $\beta$, in which the activity increased with $\left[\mathrm{Cl}^{-}\right]$; in both cases in the presence of nigericin and tributyltin (Clauzure et al., 2017; Zhang et al., 2018). We cannot explain these apparent discrepancies, but perhaps the membrane potential changes when the $\left[\mathrm{Cl}^{-}\right]_{\mathrm{e}}$ is modified, displacing the biphasic $\mathrm{Cl}^{-}$curve towards lower $\left[\mathrm{Cl}^{-}\right]$such that a reduction in the $\left[\mathrm{Cl}^{-}\right]_{\mathrm{i}}$ increases the expression of JNK and IL$1 \beta$-associated responses. The effects of changing $\left[\mathrm{Cl}^{-}\right]_{\mathrm{e}}$ on $\left[\mathrm{Cl}^{-}\right]_{\mathrm{i}}$, membrane potential, cell volume and molecular crowding are not yet understood; all these variables might influence the dose-response curve for $\mathrm{Cl}^{-}$, giving apparently contradictory results. Since the NLRP3 inflammasome is involved in maturation and secretion of IL-1 $\beta$, we are now studying the effects of $\mathrm{Cl}^{-}$on NLRP3, caspase-1, and SGK1, and the mechanisms involved in these effects. The CFTR- $\mathrm{Cl}^{-}-\mathrm{IL}-1 \beta$ signalling mechanism is illustrated in Fig. 1.

\section{CONCLUSIONS}

(1) A role of $\mathrm{Cl}^{-}$as a signalling anion has been observed both in bacterial and mammalian cells, implying a conserved function of $\mathrm{Cl}^{-}$as second messenger. 
(2) $\mathrm{Cl}^{-}$behaves as a signalling effector, modulating the activity of channels, enzymes, signalling kinases, and the expression of specific genes.

(3) Results obtained using differential display suggest that $\mathrm{Cl}^{-}$acts as a second messenger regulating the expression of many specific genes.

(4) The mechanisms by which $\mathrm{Cl}^{-}$acts are unclear. These mechanisms could be direct and highly specific to $\mathrm{Cl}^{-}$targets, e.g. possible effects on RUNX1, WNK, and SGK1, or indirect and less specific, e.g. changes in membrane potential or cell volume.

(5) It is important to distinguish between specific effects of $\mathrm{Cl}^{-}$and general or nonspecific ionic/charge effects, such as those involving membrane potential, cell volume changes or crowding effects, which could also be modulated by other ions (i.e. $\mathrm{PO}_{4} \mathrm{H}_{2}{ }^{-}$, $\mathrm{HCO}_{3}{ }^{-}, \mathrm{Na}^{+}, \mathrm{K}^{+}$, etc.). We used a double-ionophore strategy (nigericin and tributyltin) to maintain intracellular $\mathrm{pH}$, cell membrane potential and cell volume constant while changing $\left[\mathrm{Cl}^{-}\right]$, to demonstrate specific $\mathrm{Cl}^{-}$effects on gene expression. However, a combination of $\mathrm{Cl}^{-}$-specific and general effects, may be present simultaneously. (6) At high $\left[\mathrm{Cl}^{-}\right]_{\mathrm{i}}, \mathrm{Cl}^{-}$behaves as a pro-inflammatory effector that induces IL-1 $\beta$ expression and secretion, which in turn starts a net of signalling mediators such as ROS, NF- $\kappa \mathrm{B}, \mathrm{p} 38$ and JNK; $\mathrm{Cl}^{-}$also stimulates pathways linked more directly to cell proliferation, such as c-Src. It also reduces the activity of the mitochondrial Complex I. (7) It has been reported recently that the kinase SGK1 responds to $\mathrm{Cl}^{-}$and might have a central role in the activation of NF-kB and in promoting the proinflammatory effects induced by $\mathrm{Cl}^{-}$.

(8) The proinflammatory effect of $\mathrm{Cl}^{-}$might explain earlier observations on diseases linking $\mathrm{Cl}^{-}$and chloride channels to inflammation and cell proliferation, such as in chronic obstructive pulmonary disease (COPD), asthma, arteriosclerosis, Alzheimer's disease and cancer. 
(9) $\mathrm{Cl}^{-}$is not an inert anion and at high intracellular concentrations may behave as a proinflammatory effector. Thus, excess $\mathrm{NaCl}$ might not only be harmful due to high levels of $\mathrm{Na}^{+}$but also to excess $\mathrm{Cl}^{-}$.

\section{ACKNOWLEDGMENTS}

We thank Romina D'Agostino and Prof. Diego Battiato for administrative assistance. We particularly thank Lutz Birnbaumer (BIOMED, UCA-CONICET) and Otto Hutter (University of Glasgow) for interesting discussions and suggestions. This work was supported by grants from the National Agency for the Promotion of Science and Technology (ANPCYT) [PICT-2015-1031 to A.G.V.], the National Scientific and Technical Research Council (CONICET) [grant PIP-2015-11220150100227 and PUE2016- 22920160100129CO] to T.A.S.-C, and the Pontifical Catholic University of Argentina (UCA 2017) to T.A.S.-C.

\section{REFERENCES}

Abeyrathne, P. D., Chami, M. \& Stahlberg, H. (2016). Biochemical and biophysical approaches to study the structure and function of the chloride channel (ClC) family of proteins. Biochimie 128-129, 154-162.

Alvarez-Leefmans, F. J. \& Delpire, E. (2010). Preface. In Physiology and Pathology of Chloride Transporters and Channels in the Nervous System, pp. ix-x. Academic Press, San Diego, CA.

Anderson, M. P., Rich, D. P., Gregory, R. J., Smith, A. E. \& Welsh, M. J. (1991). Generation of cAMP-activated chloride currents by expression of CFTR. Science 251, 679-682.

Antigny, F., Norez, C., Dannhoffer, L., Bertrand, J., Raveau, D., Corbi, P., JAYLE, C., BECQ, F. \& VAnDEBRoucK, C. (2011). Transient receptor potential 
canonical channel 6 links $\mathrm{Ca}^{2+}$ mishandling to cystic fibrosis transmembrane conductance regulator channel dysfunction in cystic fibrosis. American Journal of Respiratory Cell and Molecular Biology 44, 83-90.

Antonenko, Y. N. \& BulycheV, A. A. (1991). Effect of phloretin on the carriermediated electrically silent ion fluxes through the bilayer lipid membrane: measurements of $\mathrm{pH}$ shifts near the membrane by $\mathrm{pH}$ microelectrode. Biochimica et Biophysica Acta 1070, 474-480.

Bachhuber, T., Konig, J., Voelcker, T., Murle, B., Schreiber, R. \& Kunzelmann, K. (2005). Cl- interference with the epithelial Na+ channel ENaC. Journal of Biological Chemistry 280, 31587-31594.

Backstrom, S., Wolf-Watz, M., Grundstrom, C., Hard, T., Grundstrom, T. \& SAUER, U. H. (2002). The RUNX1 Runt domain at 1.25A resolution: a structural switch and specifically bound chloride ions modulate DNA binding. Journal of Molecular Biology 322, 259-272.

BARON, J. H. (1973). One-hundred-and-fifty years of measurements of hydrochloric acid in gastric juice. British Medical Journal 4, 600-601.

Barrett, K. E., Barman, S. M., Boitano, S. \& Brooks, H. (2015). Ganong's Review of Medical Physiology 25th Edition. McGraw-Hill, New York, NY.

Barro-Soria, R., Aldehni, F., Almaca, J., Witzgall, R., Schreiber, R. \& KUNZELMANN, K. (2010). ER-localized bestrophin 1 activates $\mathrm{Ca}^{2+}$-dependent ion channels TMEM16A and SK4 possibly by acting as a counterion channel. Pflügers Archiv. European Journal of Physiology 459, 485-497.

Barro Soria, R., SPITZner, M., Schreiber, R. \& KunZelmann, K. (2009). Bestrophin-1 enables $\mathrm{Ca}^{2+}$-activated $\mathrm{Cl}^{-}$conductance in epithelia. Journal of Biological Chemistry 284, 29405-29412. 
Bazua-Valenti, S., Chavez-Canales, M., Rojas-Vega, L., Gonzalez-Rodriguez, X., Vazquez, N., Rodriguez-Gama, A., Argaiz, E. R., Melo, Z., Plata, C., Ellison, D. H., Garcia-VAldes, J., Hadchouel, J. \& Gamba, G. (2015). The Effect of WNK4 on the Na+-Cl- Cotransporter Is Modulated by Intracellular Chloride. Journal of the American Society of Nephrology 26, 1781-1786.

BEKAR, L. K. \& WALZ, W. (1999). Evidence for chloride ions as intracellular messenger substances in astrocytes. Journal of Neurophysiology 82, 248-254.

Berend, K., van Hulsteijn, L. H. \& Gans, R. O. B. (2012). Chloride: the queen of electrolytes? European Journal of Internal Medicine 23, 203-211.

Berger, H. A., Travis, S. M. \& Welsh, M. J. (1993). Regulation of the cystic fibrosis transmembrane conductance regulator $\mathrm{Cl}$ - channel by specific protein kinases and protein phosphatases. Journal of Biological Chemistry 268, 2037-2047.

Birkenhager, R., Otto, E., Schurmann, M. J., Vollmer, M., Ruf, E. M., MaIERLutz, I., Beekmann, F., Fekete, A., Omran, H., Feldmann, D., Milford, D. V., Jeck, N., Konrad, M., Landau, D., KnOers, N. V., ET aL. (2001). Mutation of BSND causes Bartter syndrome with sensorineural deafness and kidney failure. Nature Genetics 29, 310-314.

Bonifacie, M., Jendrzejewski, N., Agrinier, P., Humler, E., Coleman, M. \& JAVOY, M. (2008). The chlorine isotope composition of Earth's mantle. Science 319, 1518-1520.

Boucherot, A., SchreIBER, R. \& Kunzelmann, K. (2001). Role of CFTR's PDZ1binding domain, $\mathrm{NBF} 1$ and $\mathrm{Cl}(-)$ conductance in inhibition of epithelial $\mathrm{Na}(+)$ channels in Xenopus oocytes. Biochimica et Biophysica Acta 1515, 64-71.

BRAUN-MENENDEZ, E. (1939). La sustancia hypertensora de la sangre del riñón isquemiado. Revista de la Sociedad Argentina de Biología 15, 420-425. 
Briel, M., Greger, R. \& Kunzelmann, K. (1998). Cl- transport by cystic fibrosis transmembrane conductance regulator (CFTR) contributes to the inhibition of epithelial $\mathrm{Na}+$ channels (ENaCs) in Xenopus oocytes co-expressing CFTR and ENaC. Journal of Physiology 508 ( Pt 3), 825-836.

Broadbent, S. D., Ramjeesingh, M., Bear, C. E., Argent, B. E., Linsdell, P. \& GRAY, M. A. (2015). The cystic fibrosis transmembrane conductance regulator is an extracellular chloride sensor. Pflügers Archiv. European Journal of Physiology 467, 1783-1794.

BuchHolz, B., Faria, D., Schley, G., Schreiber, R., EcKardT, K. U. \& KunZELMANN, K. (2014). Anoctamin 1 induces calcium-activated chloride secretion and proliferation of renal cyst-forming epithelial cells. Kidney International 85, 1058-1067.

BunNING, P. (1983). The catalytic mechanism of angiotensin converting enzyme. Clinical and Experimental Hypertension. Part A: Theory and Practice 5, 12631275.

Busch, R. (1990). On the history of cystic fibrosis. Acta Universitatis Carolinae: Medica 36, 13-15.

Cabrita, I., Benedetto, R., Fonseca, A., Wanitchakool, P., Sirianant, L., Skryabin, B. V., SchenK, L. K., PAVenstadt, H., Schreiber, R. \& KunZELMANN, K. (2017). Differential effects of anoctamins on intracellular calcium signals. Federation of American Societies for Experimental Biology Journal 31, 2123-2134.

Cafferata, E. G., Gonzalez-Guerrico, A. M., Giordano, L., Pivetta, O. H. \& SANTA-ColOMA, T. A. (2000). Interleukin-1beta regulates CFTR expression in human intestinal T84 cells. Biochim Biophys Acta 1500, 241-8. 
Cafferata, E. G., González-Guerrico, A., Pivetta, O. H. \& Santa-Coloma, T. A. (1995). Abstract M99 [Identificación mediante “differential display” de genes específicamente regulados por diferentes factores que afectan la expresión del CFTR (canal de cloro afectado en Fibrosis Quística)] Abstracts of the 31th Annual Meeting of the Argentine Society for Biochemistry and Molecular Biology Research, 15-18 November, Villa Giardino, Córdoba, Argentina. Abstracs Book.

Cafferata, E. G., Gonzalez-Guerrico, A. M., Pivetta, O. H. \& Santa-Coloma, T. A. (1996). Identification by differential display of a mRNA specifically induced by 12-O-tetradecanoylphorbol-13-acetate (TPA) in T84 human colon carcinoma cells. Cell Mol Biol (Noisy-le-grand) 42, 797-804.

Cafferata, E. G. A., González Guerrico, A. M., Pivetta, O. H. \& Santa-Coloma, T. A. (1997). Abstract “Up- Regulation of CFTR expression by interleukin 1beta in T84 cells" in The Cystic Fibrosis Foundation Presents The Eleventh Annual North American Cystic Fibrosis Conference: Nashville, Tennessee, October 23-26 Pediatric Pulmonology 14, 71-352.

Cafferata, E. G., Guerrico, A. M., Pivetta, O. H. \& Santa-Coloma, T. A. (2001). NF-kappaB activation is involved in regulation of cystic fibrosis transmembrane conductance regulator (CFTR) by interleukin-1beta. J Biol Chem 276, 15441-4. CARugo, O. (2014). Buried chloride stereochemistry in the Protein Data Bank. BioMed Central Structural Biology 14, 19.

Chan, M. M., ChMurA, K. \& ChAN, E. D. (2006). Increased NaCl-induced interleukin8 production by human bronchial epithelial cells is enhanced by the DeltaF508/W1282X mutation of the cystic fibrosis transmembrane conductance regulator gene. Cytokine 33, 309-316. 
Chang, S. Y., Di, A., NAren, A. P., Palfrey, H. C., Kirk, K. L. \& Nelson, D. J. (2002). Mechanisms of CFTR regulation by syntaxin 1A and PKA. Journal of Cell Science 115, 783-791.

ChaO, A. C., DiX, J. A., Sellers, M. C. \& Verkman, A. S. (1989). Fluorescence measurement of chloride transport in monolayer cultured cells. Mechanisms of chloride transport in fibroblasts. Biophysical Journal 56, 1071-1081.

Charreau, E. H. (2016). [Bernardo A. Houssay (1887-1971)]. Revista Argentina de Endocrinologia y Metabolismo 53, 1-4.

Chen, J. C., Lo, Y. F., Lin, Y. W., Lin, S. H., HuAng, C. L. \& Cheng, C. J. (2019). WNK4 kinase is a physiological intracellular chloride sensor. Proceedings of the National Academy of Sciences of the United States of America 116, 4502-4507.

ChEn, T. Y. \& HwAng, T. C. (2008). CLC-0 and CFTR: chloride channels evolved from transporters. Physiological Reviews 88, 351-387.

Cheng, H. F., Wang, J. L., Zhang, M. Z., McKanna, J. A. \& Harris, R. C. (2000). Role of $\mathrm{p} 38$ in the regulation of renal cortical cyclooxygenase- 2 expression by extracellular chloride. Journal of Clinical Investigation 106, 681-688.

CHENG, Y. \& LOTAN, R. (1998). Molecular cloning and characterization of a novel retinoic acid-inducible gene that encodes a putative $\mathrm{G}$ protein-coupled receptor. Journal of Biological Chemistry 273, 35008-35015.

Choi, H., Ettinger, N., Rohrbough, J., Dikalova, A., Nguyen, H. N. \& Lamb, F. S. (2016). LRRC8A channels support TNF $\alpha$-induced superoxide production by Nox 1 which is required for receptor endocytosis. Free Radical Biology \& Medicine 101, 413-423. 
Choi, J. Y., Lee, M. G., Ko, S. \& Muallem, S. (2001). Cl(-)-dependent HCO3transport by cystic fibrosis transmembrane conductance regulator. Journal d'Optique 2, 243-246.

Cigic, B. \& PAIN, R. H. (1999). Location of the binding site for chloride ion activation of cathepsin C. European Journal of Biochemistry 264, 944-951.

Claisse, G., Feller, G., Bonneau, M. \& Da Lage, J. L. (2016). A single amino-acid substitution toggles chloride dependence of the alpha-amylase paralog amyrel in Drosophila melanogaster and Drosophila virilis species. Insect Biochemistry and Molecular Biology 75, 70-77.

Clauzure, M., Valdivieso, A. G., Massip Copiz, M. M., Schulman, G., Teiber, M. L. \& SANTA-Coloma, T. A. (2014). Disruption of interleukin-1beta autocrine signaling rescues complex I activity and improves ROS levels in immortalized epithelial cells with impaired cystic fibrosis transmembrane conductance regulator (CFTR) function. PloS One $\mathbf{9}$, e99257.

Clauzure, M., Valdivieso, A. G., Massip-Copiz, M. M., Mori, C., Dugour, A. V., FigueroA, J. M. \& SANTA-COlOMA, T. A. (2017). Intracellular Chloride Concentration Changes Modulate IL-1beta Expression and Secretion in Human Bronchial Epithelial Cultured Cells. Journal of Cellular Biochemistry 118, $2131-2140$.

COLEMAN, W. J. (1990). Chloride binding proteins: mechanistic implications for the oxygen-evolving complex of Photosystem II. Photosynthesis Research 23, 1-27.

Crutzen, R., Virreira, M., Markadieu, N., Shlyonsky, V., Sener, A., Malaisse, W. J., Beauwens, R., Boom, A. \& Golstein, P. E. (2016). Anoctamin 1 (Ano1) is required for glucose-induced membrane potential oscillations and insulin 
secretion by murine beta-cells. Pflügers Archiv. European Journal of Physiology 468, 573-591.

De Biase, D. \& PENNACChIETTI, E. (2012). Glutamate decarboxylase-dependent acid resistance in orally acquired bacteria: function, distribution and biomedical implications of the gadBC operon. Molecular Microbiology 86, 770-786.

DEWolf, W. C. (1977). Sydney Ringer (1835-1910). Investigative Urology 14, 500501.

DOWD, B. F. \& FORBUSH, B. (2003). PASK (proline-alanine-rich STE20-related kinase), a regulatory kinase of the Na-K-Cl cotransporter (NKCC1). Journal of Biological Chemistry 278, 27347-27353.

Duran, C., Thompson, C. H., XiaO, Q. \& Hartzell, H. C. (2010). Chloride channels: often enigmatic, rarely predictable. Annual Review of Physiology 72, 95-121.

Duvvuri, U., Shiwarski, D. J., Xiao, D., Bertrand, C., Huang, X., Edinger, R. S., Rock, J. R., Harfe, B. D., Henson, B. J., Kunzelmann, K., Schreiber, R., Seethala, R. S., Egloff, A. M., Chen, X., LuI, V. W., ET AL.. (2012). TMEM16A induces MAPK and contributes directly to tumorigenesis and cancer progression. Cancer Research 72, 3270-3281.

Estell, K., Braunstein, G., Tucker, T., Varga, K., Collawn, J. F. \& Schwiebert, L. M. (2003). Plasma membrane CFTR regulates RANTES expression via its Cterminal PDZ-interacting motif. Molecular and Cellular Biology 23, 594-606.

Estevez, R., Boettger, T., Stein, V., Birkenhager, R., Otto, E., Hildebrandt, F. \& JENTSCH, T. J. (2001). Barttin is a Cl- channel beta-subunit crucial for renal Cl- reabsorption and inner ear $\mathrm{K}+$ secretion. Nature 414, 558-561.

Faria, D., Rock, J. R., RomaO, A. M., SchWEdA, F., BANDUlik, S., WitzGall, R., Schlatter, E., Heitzmann, D., Pavenstadt, H., Herrmann, E., 
KunZelmann, K. \& Schreiber, R. (2014). The calcium-activated chloride channel Anoctamin 1 contributes to the regulation of renal function. Kidney International 85, 1369-1381.

FAsciolo, J. C., Houssay, B. A. \& TAquini, A. C. (1938). The blood-pressure raising secretion of the ischaemic kidney. Journal of Physiology 94, 281-293.

FASCIOLO, J. C. (1990). Basso. Hypertension 16, 194-198.

Feller, G., Bussy, O., Houssier, C. \& Gerday, C. (1996). Structural and functional aspects of chloride binding to Alteromonas haloplanctis alpha-amylase. Journal of Biological Chemistry 271, 23836-23841.

Fiedler, T. J., DAVEy, C. A. \& Fenna, R. E. (2000). X-ray crystal structure and characterization of halide-binding sites of human myeloperoxidase at $1.8 \mathrm{~A}$ resolution. Journal of Biological Chemistry 275, 11964-11971.

FINK, R. H. \& VEIGEL, C. (1996). Calcium uptake and release modulated by counter-ion conductances in the sarcoplasmic reticulum of skeletal muscle. Acta Physiologica Scandinavica 156, 387-396.

FisCHER, H. \& MACHEN, T. E. (1996). The tyrosine kinase p60c-src regulates the fast gate of the cystic fibrosis transmembrane conductance regulator chloride channel. Biophysical Journal 71, 3073-3082.

Forschbach, V., Goppelt-Struebe, M., KunZelmann, K., Schreiber, R., Piedagnel, R., Kraus, A., Eckardt, K. U. \& Buchholz, B. (2015). Anoctamin 6 is localized in the primary cilium of renal tubular cells and is involved in apoptosis-dependent cyst lumen formation. Cell Death \& Disease 6 , e1899.

FrIZZELL, R. A. (1999). Ten years with CFTR. Physiological Reviews 79, S1-2. 
Funabashi, K., Fuji, M., Yamamura, H., OHYa, S. \& Imaizumi, Y. (2010).

Contribution of chloride channel conductance to the regulation of resting membrane potential in chondrocytes. Journal of Pharmacological Sciences 113, 94-99.

Gagnon, K. B., England, R. \& Delpire, E. (2006a). Volume sensitivity of cation-Clcotransporters is modulated by the interaction of two kinases: Ste20-related proline-alanine-rich kinase and WNK4. American Journal of Physiology Cell Physiology 290, C134-142.

Gagnon, K. B., England, R. \& DelPIRE, E. (2006b). Characterization of SPAK and OSR1, regulatory kinases of the $\mathrm{Na}-\mathrm{K}-2 \mathrm{Cl}$ cotransporter. Molecular and Cellular Biology 26, 689-698.

Galvin, P., Clarke, L. A., Harvey, S. \& Amaral, M. D. (2004). Microarray analysis in cystic fibrosis. Journal of Cystic Fibrosis 3 Suppl 2, 29-33.

Gonzalez-Guerrico, A. M., Cafferata, E. G., Radrizzani, M., Marcucci, F., Gruenert, D., Pivetta, O. H., Favaloro, R. R., Laguens, R., Perrone, S. V., Gallo, G. C. \& SANTA-Coloma, T. A. (2002). Tyrosine kinase c-Src constitutes a bridge between cystic fibrosis transmembrane regulator channel failure and MUC1 overexpression in cystic fibrosis. Journal of Biological Chemistry 277, 17239-17247.

Gut, H., Pennacchietti, E., John, R. A., Bossa, F., Capitani, G., De Biase, D. \& GRUTTER, M. G. (2006). Escherichia coli acid resistance: pH-sensing, activation by chloride and autoinhibition in GadB. EMBO J 25, 2643-51.

HAAs, M., MCBRAYER, D. \& LYTLE, C. (1995). [Cl-]i-dependent phosphorylation of the $\mathrm{Na}-\mathrm{K}-\mathrm{Cl}$ cotransport protein of dog tracheal epithelial cells. Journal of Biological Chemistry 270, 28955-28961. 
Hammer, C., Wanitchakool, P., Sirianant, L., Papiol, S., Monnheimer, M., Faria, D., Ousingsawat, J., SchrameK, N., Schmitt, C., Margos, G., Michel, A., Kraiczy, P., Pawlita, M., Schreiber, R., Schulz, T. F., ET AL. (2015). A Coding Variant of ANO10, Affecting Volume Regulation of Macrophages, Is Associated with Borrelia Seropositivity. Molecular Medicine 21, 26-37. Hartzell, H. C. (2010). Chapter 1 - Chloride Channels: An Historical Perspective. In Physiology and Pathology of Chloride Transporters and Channels in the Nervous System (ed. F. J. Alvarez-Leefmans and E. Delpire), pp. 1-15. Academic Press, San Diego.

HeIMlich, G. \& CidlowsKi, J. A. (2006). Selective role of intracellular chloride in the regulation of the intrinsic but not extrinsic pathway of apoptosis in Jurkat Tcells. Journal of Biological Chemistry 281, 2232-2241.

HiRAOKA, K., MiYaZaki, H., NiISATo, N., Iwasaki, Y., Kawauchi, A., Miki, T. \& MARUNAKA, Y. (2010). Chloride ion modulates cell proliferation of human androgen-independent prostatic cancer cell. Cellular Physiology and Biochemistry 25, 379-388.

Hoffmann, E. K., Sorensen, B. H., SAuter, D. P. \& LAMBert, I. H. (2015). Role of volume-regulated and calcium-activated anion channels in cell volume homeostasis, cancer and drug resistance. Channels (Austin) 9, 380-396.

Houssay, B. A. \& Buzzo, A. (1937). [Juan B. Señorans Iniciador de la medicina experimental en la República Argentina]. Imprenta y casa editora Coni, Buenos Aires.

Houssay, B. A., Lewis, J. T. \& ORIAs, O. (1951). Human Physiology, First Edition edition. McGraw-Hill, New York, NY. 
HuANG, C. L. \& CHENG, C. J. (2015). A unifying mechanism for WNK kinase regulation of sodium-chloride cotransporter. Pflügers Archiv. European Journal of Physiology 467, 2235-2241.

HubneR, C. A. \& Jentsch, T. J. (2008). Channelopathies of transepithelial transport and vesicular function. Advances in Genetics 63, 113-152.

HutTER, O. F. (2017). A personal historic perspective on the role of chloride in skeletal and cardiac muscle. Physiological Reports 5, e13165.

IRVING, L. (1965). Claude Bernard's Introduction to the Study of Experimental Medicine. Journal of the American Medical Association 193, 1043-1043.

ITO, S. (2016). GABA and glycine in the developing brain. Journal of Physiological Sciences 66, 375-379.

Jentsch, T. J., MARitZEn, T. \& ZDEBIK, A. A. (2005). Chloride channel diseases resulting from impaired transepithelial transport or vesicular function. Journal of Clinical Investigation 115, 2039-2046.

Jiang, Q., MaK, D., Devidas, S., Schwiebert, E. M., Bragin, A., Zhang, Y., SKach, W. R., Guggino, W. B., Foskett, J. K. \& Engelhardt, J. F. (1998). Cystic fibrosis transmembrane conductance regulator-associated ATP release is controlled by a chloride sensor. Journal of Cell Biology 143, 645-657.

Jin, X., Shah, S., Du, X., Zhang, H. \& GAmPer, N. (2016). Activation of Ca(2+) activated $\mathrm{Cl}(-)$ channel $\mathrm{ANO} 1$ by localized $\mathrm{Ca}(2+)$ signals. Journal of Physiology 594, 19-30.

Juul, C. A., Grubb, S., Poulsen, K. A., Kyed, T., Hashem, N., LAmbert, I. H., LARSEN, E. H. \& HofFMANN, E. K. (2014). Anoctamin 6 differs from VRAC and VSOAC but is involved in apoptosis and supports volume regulation in the 
presence of $\mathrm{Ca}^{2+}$. Pflügers Archives. European Journal of Physiology 466, $1899-1910$.

Kamaleddin, M. A. (2018). Molecular, Biophysical, and Pharmacological Properties of Calcium-Activated Chloride Channels. Journal of Cellular Physiology 233, $787-798$.

Kerem, B., Rommens, J. M., Buchanan, J. A., Markiewicz, D., Cox, T. K., Chakravarti, A., Buchwald, M. \& Tsui, L. C. (1989). Identification of the cystic fibrosis gene: genetic analysis. Science 245, 1073-1080.

Klausen, T. K., Preisler, S., Pedersen, S. F. \& Hoffmann, E. K. (2010). Monovalent ions control proliferation of Ehrlich Lettre ascites cells. American Journal of Physiology Cell Physiology 299, C714-725.

Koch, M. C., Steinmeyer, K., Lorenz, C., Ricker, K., Wolf, F., Otto, M., Zoll, B., LEHMANN-Horn, F., GRZESCHIK, K. H. \& JENTSCH, T. J. (1992). The skeletal muscle chloride channel in dominant and recessive human myotonia. Science 257, 797-800.

Konig, J., Schreiber, R., Voelcker, T., Mall, M. \& Kunzelmann, K. (2001). The cystic fibrosis transmembrane conductance regulator (CFTR) inhibits $\mathrm{ENaC}$ through an increase in the intracellular Cl- concentration. European Molecular Biology Organization Reports 2, 1047-1051.

Kornak, U., Kasper, D., Bosl, M. R., KaISer, E., SchweIZer, M., Schulz, A., Friedrich, W., DELling, G. \& JENTSCH, T. J. (2001). Loss of the ClC-7 chloride channel leads to osteopetrosis in mice and man. Cell 104, 205-215.

Kousoulis, A. A., Tsoucalas, G., Armenis, I., Marineli, F., Karamanou, M. \& ANDROUTSOS, G. (2012). From the "hungry acid" to pepsinogen: a journey 
through time in quest for the stomach's secretion. Annls Gastroenterology 25, $119-122$.

Krall, J., Balle, T., Krogsgaard-Larsen, N., Sorensen, T. E., KrogsgaArDLarsen, P., Kristiansen, U. \& Frolund, B. (2015). GABAA receptor partial agonists and antagonists: structure, binding mode, and pharmacology. Advances in Pharmacology 72, 201-227.

KRAPF, R., BERRY, C. A. \& VERKMAN, A. S. (1988). Estimation of intracellular chloride activity in isolated perfused rabbit proximal convoluted tubules using a fluorescent indicator. Biophysical Journal 53, 955-962.

KunZelmanN, K. \& MALl, M. (2002). Electrolyte transport in the mammalian colon: mechanisms and implications for disease. Physiological Reviews 82, 245-289.

KunZELMANN, K. (2003). ENaC is inhibited by an increase in the intracellular Cl(-) concentration mediated through activation of $\mathrm{Cl}(-)$ channels. Pflügers Archives European Journal of Physiology 445, 504-512.

Kunzelmann, K., Kongsuphol, P., Aldehni, F., Tian, Y., Ousingsawat, J., Warth, R. \& SCHREIBER, R. (2009). Bestrophin and TMEM16-Ca(2+) activated Cl(-) channels with different functions. Cell Calcium 46, 233-241.

Kunzelmann, K., Kongsuphol, P., Chootip, K., Toledo, C., Martins, J. R., Almaca, J., Tian, Y., WitzGall, R., Ousingsawat, J. \& Schreiber, R. (2011a). Role of the $\mathrm{Ca}^{2+}$-activated $\mathrm{Cl}^{-}$channels bestrophin and anoctamin in epithelial cells. Biological Chemistry 392, 125-134.

Kunzelmann, K., Tian, Y., Martins, J. R., Faria, D., Kongsuphol, P., Ousingsawat, J., Thevenod, F., Roussa, E., Rock, J. \& Schreiber, R. (2011b). Anoctamins. Pflügers Archives - European Journal of Physiology 462, 195-208. 
Kunzelmann, K., Tian, Y., Martins, J. R., Faria, D., Kongsuphol, P., Ousingsawat, J., Wolf, L. \& SchreIBER, R. (2012). Airway epithelial cells functional links between CFTR and anoctamin dependent Cl- secretion. International Journal of Biochemistry \& Cell Biology 44, 1897-1900.

KunZelmann, K. \& Schreiber, R. (2014). Chloride secretion, anoctamin 1 and $\mathrm{Ca}(2+)$ signaling. Channels (Austin) 8, 387-388.

KUNZELMANN, K. (2015). TMEM16, LRRC8A, bestrophin: chloride channels controlled by $\mathrm{Ca}(2+)$ and cell volume. Trends in Biochemical Sciences 40, 535543.

KunZelmann, K. (2016). Ion channels in regulated cell death. Cellular and Molecular Life Sciences 73, 2387-2403.

Kunzelmann, K., Cabrita, I., Wanitchakool, P., Ousingsawat, J., Sirianant, L., BEnedetto, R. \& Schreiber, R. (2016). Modulating Ca(2)(+) signals: a common theme for TMEM16, Ist2, and TMC. Pflügers Archives - European Journal of Physiology 468, 475-490.

LAI, Z. F., CHEN, Y. Z. \& NISHI, K. (2003). Modulation of intracellular Cl- homeostasis by lectin-stimulation in Jurkat T lymphocytes. European Journal of Pharmacology 482, 1-8.

LAURIE, D. J., Wisden, W. \& SEEBURG, P. H. (1992). The distribution of thirteen GABAA receptor subunit mRNAs in the rat brain. III. Embryonic and postnatal development. Journal of Neuroscience 12, 4151-4172.

LeE, M. G., Ohana, E., Park, H. W., Yang, D. \& Muallem, S. (2012). Molecular mechanism of pancreatic and salivary gland fluid and $\mathrm{HCO} 3$ secretion. Physiological Reviews 92, 39-74. 
Lerias, J., Pinto, M., Benedetto, R., Schreiber, R., Amaral, M., Aureli, M. \& KunZELMANN, K. (2018a). Compartmentalized crosstalk of CFTR and TMEM16A (ANO1) through EPAC1 and ADCY1. Cellular Signalling 44, 1019.

Lerias, J. R., Pinto, M. C., Botelho, H. M., Awatade, N. T., Quaresma, M. C., Silva, I. A. L., Wanitchakool, P., Schreiber, R., PePPeRKoK, R., KunZelmann, K. \& AmARAL, M. D. (2018b). A novel microscopy-based assay identifies extended synaptotagmin-1 (ESYT1) as a positive regulator of anoctamin 1 traffic. Biochimica et Biophysica Acta Molecular Cell Research 1865, 421-431.

LIANG, W., RAY, J. B., HE, J. Z., BACKX, P. H. \& WARD, M. E. (2009). Regulation of proliferation and membrane potential by chloride currents in rat pulmonary artery smooth muscle cells. Hypertension 54, 286-293.

LiU, F., Zhang, Z., Csanady, L., Gadsby, D. C. \& Chen, J. (2017). Molecular Structure of the Human CFTR Ion Channel. Cell 169, 85-95 e88.

Liu, X., Fernandez, M., Wouters, M. A., Heyberger, S. \& Husain, A. (2001). $\operatorname{Arg}(1098)$ is critical for the chloride dependence of human angiotensin Iconverting enzyme C-domain catalytic activity. Journal of Biological Chemistry 276, 33518-33525.

LYTLE, C. \& FoRBUSH, B., III. (1992). The Na-K-Cl cotransport protein of shark rectal gland. II. Regulation by direct phosphorylation. Journal of Biological Chemistry 267, 25438-25443.

MACLEOD, R. A. \& ONOFREY, E. (1956). Nutrition and metabolism of marine bacteria. II. Observations on the relation of sea water to the growth of marine bacteria. Journal of Bacteriology 71, 661-667. 
MACLEOD, R. A. \& ONOFREY, E. (1957). Nutrition and metabolism of marine bacteria.

VI. Quantitative requirements for halides, magnesium, calcium, and iron.

Canadian Journal of Microbiology 3, 753-759.

Mahaut-Smith, M. P., TAYlor, K. A. \& Evans, R. J. (2016). Calcium Signalling through Ligand-Gated Ion Channels such as P2X1 Receptors in the Platelet and other Non-Excitable Cells. Advances in Experimental Medicine and Biology 898, 305-329.

Makoul, G. T., Robinson, D. R., Bhalla, A. K. \& Glimcher, L. H. (1985). Prostaglandin E2 inhibits the activation of cloned T cell hybridomas. Journal of Immunology 134, 2645-2650.

Maldonado, D., Schumann, M., NGhiem, P., Dong, Y. \& Gardner, P. (1991). Prostaglandin E1 activates a chloride current in Jurkat T lymphocytes via cAMP-dependent protein kinase. Federation of American Societies for Experimental Biology Journal 5, 2965-2970.

Martins, J. R., Kongsuphol, P., Sammels, E., Dahimene, S., Aldehni, F., Clarke, L. A., Schreiber, R., DE Smedt, H., Amaral, M. D. \& Kunzelmann, K. (2011). F508del-CFTR increases intracellular $\mathrm{Ca}(2+)$ signaling that causes enhanced calcium-dependent $\mathrm{Cl}(-)$ conductance in cystic fibrosis. Biochimica et Biophysica Acta 1812, 1385-1392.

Massip-Copiz, M. M., Clauzure, M., Valdivieso, A. G. \& Santa-Coloma, T. A. (2017). CFTR impairment upregulates c-Src activity through IL-1beta autocrine signaling. Archives of Biochemistry and Biophysics 616, 1-12.

Massip-Copiz, M., Clauzure, M., Valdivieso, A. G. \& SAnta-Coloma, T. A. (2018). Epiregulin (EREG) is upregulated through an IL-1beta autocrine loop in 
Caco-2 epithelial cells with reduced CFTR function. Journal of Cellular Biochemistry 119, 2911-2922.

Massip-Copiz, M. M. \& SANTA-Coloma, T. A. (2018). Extracellular pH and lung infections in cystic fibrosis. European Journal of Cell Biology 97, 402-410.

Massip CoPIZ, M. M. \& SANTA COLOMA, T. A. (2016). c- Src and its role in cystic fibrosis. European Journal of Cell Biology 95, 401-413.

Masuyer, G., Yates, C. J., Sturrock, E. D. \& Acharya, K. R. (2014). Angiotensin-I converting enzyme (ACE): structure, biological roles, and molecular basis for chloride ion dependence. Biological Chemistry 395, 1135-1149.

Matsuda, J. J., Filali, M. S., Moreland, J. G., Miller, F. J. \& Lamb, F. S. (2010). Activation of swelling-activated chloride current by tumor necrosis factor-alpha requires ClC-3-dependent endosomal reactive oxygen production. Journal of Biological Chemistry 285, 22864-22873.

Maurus, R., Begum, A., Kuo, H. H., Racaza, A., Numao, S., Andersen, C., Tams, J. W., Vind, J., Overall, C. M., Withers, S. G. \& Brayer, G. D. (2005). Structural and mechanistic studies of chloride induced activation of human pancreatic alpha-amylase. Protein Science 14, 743-755.

McCallum, L., LiP, S. \& Padmanabhan, S. (2015). The hidden hand of chloride in hypertension. Pflügers Archives - European Journal of Physiology 467, 595603.

Menegazzi, R., Busetto, S., Cramer, R., Dri, P. \& Patriarca, P. (2000). Role of intracellular chloride in the reversible activation of neutrophil beta 2 integrins: a lesson from TNF stimulation. Journal of Immunology 165, 4606-4614. 
Menendez, E. B., Fasciolo, J. C., Houssay, B. A., Leloir, L. F., Munoz, J. M. \& TAQUini, A. C. (1943). ANGIOTONIN OR HYPERTENSIN. Science 98, 495.

MiLLER, D. J. (2004). Sydney Ringer; physiological saline, calcium and the contraction of the heart. Journal of Physiology 555, 585-587.

Miller, F. J., JR., Filali, M., Huss, G. J., Stanic, B., Chamseddine, A., Barna, T. J. \& LAMB, F. S. (2007). Cytokine activation of nuclear factor kappa B in vascular smooth muscle cells requires signaling endosomes containing Nox 1 and ClC-3. Circulation Research 101, 663-671.

MiyaZaki, H., Shiozaki, A., NiISATo, N., Ohsawa, R., Itoi, H., Ueda, Y., Otsuji, E., YAMAGISHI, H., IWASAKI, Y., NAKANO, T., NAKAHARI, T. \& MARUNAKA, Y. (2008). Chloride ions control the G1/S cell-cycle checkpoint by regulating the expression of p21 through a p53-independent pathway in human gastric cancer cells. Biochemical and Biophysical Research Communications 366, 506-512.

Moriguchi, T., Urushiyama, S., Hisamoto, N., IEmura, S., Uchida, S., NAtsume, T., Matsumoto, K. \& ShiBuYA, H. (2005). WNK1 regulates phosphorylation of cation-chloride-coupled cotransporters via the STE20-related kinases, SPAK and OSR1. Journal of Biological Chemistry 280, 42685-42693.

MoriyAma, Y. \& Nelson, N. (1987). The purified ATPase from chromaffin granule membranes is an anion-dependent proton pump. Journal of Biological Chemistry 262, 9175-9180.

MulleR, V. \& OREN, A. (2003). Metabolism of chloride in halophilic prokaryotes. Extremophiles 7, 261-266.

Murray, J. W., Maghlaoui, K., Kargul, J., Ishida, N., Lai, T.-L., Rutherford, A. W., Sugiura, M., Boussac, A. \& BArber, J. (2008). X-ray crystallography 
identifies two chloride binding sites in the oxygen evolving centre of Photosystem II. Energy \& Environmental Science 1, 161-166.

NAKAJIMA, K. I. \& MARUNAKA, Y. (2016). Intracellular chloride ion concentration in differentiating neuronal cell and its role in growing neurite. Biochemical and Biophysical Research Communications 479, 338-342.

Nakajima, T., Sugimoto, T. \& Kurachi, Y. (1992). Effects of anions on the G protein-mediated activation of the muscarinic $\mathrm{K}+$ channel in the cardiac atrial cell membrane. Intracellular chloride inhibition of the GTPase activity of GK. Journal of General Physiology 99, 665-682.

Nitsato, N., EAton, D. C. \& MARUnAKA, Y. (2004). Involvement of cytosolic Cl- in osmoregulation of alpha-ENaC gene expression. American Journal of Physiology: Renal Physiology 287, F932-939.

NiISATO, N., TARUnO, A. \& MARUNAKA, Y. (2007). Involvement of p38 MAPK in hypotonic stress-induced stimulation of beta- and gamma-ENaC expression in renal epithelium. Biochemical and Biophysical Research Communications $\mathbf{3 5 8}$ 819-824.

Nilius, B., Prenen, J., Droogmans, G., Voets, T., Vennekens, R., Freichel, M., WisSENBACH, U. \& FlOCKERZI, V. (2003). Voltage dependence of the $\mathrm{Ca}^{2+}$ activated cation channel TRPM4. Journal of Biological Chemistry 278, 3081330820

Nunes, P., Roth, I., Meda, P., Feraille, E., Brown, D. \& Hasler, U. (2015). Ionic imbalance, in addition to molecular crowding, abates cytoskeletal dynamics and vesicle motility during hypertonic stress. Proceedings of the National Academy of Sciences of the United States of America 112, E3104-3113. 
OH, U. \& JUNG, J. (2016). Cellular functions of TMEM16/anoctamin. Pflügers Archives - European Journal of Physiology 468, 443-453.

Ohsawa, R., MiYaZaki, H., NiISATo, N., ShiOzaki, A., IwaSAKi, Y., Otsuji, E. \& MARUNAKA, Y. (2010). Intracellular chloride regulates cell proliferation through the activation of stress-activated protein kinases in MKN28 human gastric cancer cells. Journal of Cellular Physiology 223, 764-770.

Olmsted, J. M. (1935). The Influence of Claude Bernard on Medicine in the United States and England: Part I. California and Western Medicine 42, 111-113.

ORLOV, S. N. \& HAMET, P. (2006). Intracellular monovalent ions as second messengers. Journal of Membrane Biology 210, 161-172.

Ousingsawat, J., Kongsuphol, P., Schreiber, R. \& Kunzelmann, K. (2011). CFTR and TMEM16A are separate but functionally related Cl- channels. Cellular Physiology and Biochemistry 28, 715-724.

Ousingsawat, J., Wanitchakool, P., Kmit, A., Romao, A. M., Jantarajt, W., SCHREIBER, R. \& KUNZELMANN, K. (2015). Anoctamin 6 mediates effects essential for innate immunity downstream of $\mathrm{P} 2 \mathrm{X} 7$ receptors in macrophages. Nature Communications 6, 6245.

Pacheco-Alvarez, D., Cristobal, P. S., Meade, P., Moreno, E., VazQuez, N., Munoz, E., Diaz, A., JuAREZ, M. E., Gimenez, I. \& GambA, G. (2006). The $\mathrm{Na}+\mathrm{Cl}-$ cotransporter is activated and phosphorylated at the amino-terminal domain upon intracellular chloride depletion. Journal of Biological Chemistry 281, 28755-28763.

PACHECO-AlvareZ, D. \& GAMBA, G. (2011). WNK3 is a putative chloride-sensing kinase. Cellular Physiology and Biochemistry 28, 1123-1134. 
PAGe, I. H. \& HelmeR, O. M. (1940). A crystalline pressor substance (angiotonin) resulting from the reaction between renin and renin-activator. Journal of Experimental Medicine 71, 29-42.

Painter, R. G., Marrero, L., Lombard, G. A., Valentine, V. G., NAuseef, W. M. \& WANG, G. (2010). CFTR-mediated halide transport in phagosomes of human neutrophils. Journal of Leukocyte Biology 87, 933-942.

Paredes, J. M., Idilli, A. I., Mariotti, L., Losi, G., Arslanbaeva, L. R., SAto, S. S., Artoni, P., Szczurkowska, J., Cancedda, L., Ratto, G. M., Carmignoto, G. \& ARosio, D. (2016). Synchronous Bioimaging of Intracellular $\mathrm{pH}$ and Chloride Based on LSS Fluorescent Protein. American Chemical Society - Chemical Biology 11, 1652-1660.

Pazoles, C. J., Creutz, C. E., Ramu, A. \& Pollard, H. B. (1980). Permeant anion activation of MgATPase activity in chromaffin granules. Evidence for direct coupling of proton and anion transport. Journal of Biological Chemistry 255, $7863-7869$.

Pedemonte, N. \& GalietTA, L. J. (2014). Structure and function of TMEM16 proteins (anoctamins). Physiological Reviews 94, 419-459.

Pedersen, S. F., Hoffmann, E. K. \& NovaK, I. (2013). Cell volume regulation in epithelial physiology and cancer. Frontiers in Physiology 4, 233.

Pedersen, T. H., Riisager, A., De Paoli, F. V., Chen, T. Y. \& Nielsen, O. B. (2016). Role of physiological ClC-1 Cl- ion channel regulation for the excitability and function of working skeletal muscle. Journal of General Physiology 147, 291308. 
Piala, A. T., Moon, T. M., Akella, R., He, H., Cobb, M. H. \& Goldsmith, E. J. (2014). Chloride sensing by WNK1 involves inhibition of autophosphorylation. Science Signaling 7, ra41.

Piechotta, K., Lu, J. \& DelpiRe, E. (2002). Cation chloride cotransporters interact with the stress-related kinases Ste20-related proline-alanine-rich kinase (SPAK) and oxidative stress response 1 (OSR1). Journal of Biological Chemistry 277, $50812-50819$.

Planells-Cases, R. \& Jentsch, T. J. (2009). Chloride channelopathies. Biochimica et Biophysica Acta 1792, 173-189.

Plans, V., Rickheit, G. \& Jentsch, T. J. (2009). Physiological roles of CLC Cl(-)/H (+) exchangers in renal proximal tubules. Pflügers Archives - European Journal of Physiology 458, 23-37.

Plested, A. J. (2011). Kainate receptor modulation by sodium and chloride. Advances in Experimental Medicine and Biology 717, 93-113.

Pohl, P., Rokitskaya, T. I., Pohl, E. E. \& Saparov, S. M. (1997). Permeation of phloretin across bilayer lipid membranes monitored by dipole potential and microelectrode measurements. Biochimica et Biophysica Acta 1323, 163-172.

PokHrel, R., McConnell, I. L. \& Brudvig, G. W. (2011). Chloride regulation of enzyme turnover: application to the role of chloride in photosystem II. Biochemistry 50, 2725-2734.

Poroca, D. R., Pelis, R. M. \& ChAPPE, V. M. (2017). ClC Channels and Transporters: Structure, Physiological Functions, and Implications in Human Chloride Channelopathies. Frontiers in Pharmacology 8, 151. 
Prange, H. D., Shoemaker, J. L., JR., Westen, E. A., Horstkotte, D. G. \& Pinshow, B. (2001). Physiological consequences of oxygen-dependent chloride binding to hemoglobin. Journal of Applied Physiology 91, 33-38.

Prout, W. (1974). On the nature of the acid and saline matters usually existing in the stomachs of animals. Gut 15, $4541-4941$.

PULJAK, L. \& KILIC, G. (2006). Emerging roles of chloride channels in human diseases. Biochimica et Biophysica Acta 1762, 404-413.

PusCH, M. (2002). Myotonia caused by mutations in the muscle chloride channel gene CLCN1. Human Mutation 19, 423-434.

Quinton, P. M. (1983). Chloride impermeability in cystic fibrosis. Nature 301, 421422.

Riazanski, V., Gabdoulkhakova, A. G., Boynton, L. S., Eguchi, R. R., Deriy, L. V., Hogarth, D. K., Loaec, N., Oumata, N., Galons, H., Brown, M. E., Shevchenko, P., Gallan, A. J., Yoo, S. G., Naren, A. P., Villereal, M. L., ET AL. (2015). TRPC6 channel translocation into phagosomal membrane augments phagosomal function. Proceedings of the National Academy of Sciences of the United States of America 112, E6486-6495.

RiNGER, S. (1859). On the Connexion between the Heat of the Body and the excreted amounts of Urea, Chloride of Sodium, and Urinary Water, during a Fit of Ague. Medico-Chirurgical Transactions 42, 361-401.

RINGER, S. (1883). A further Contribution regarding the influence of the different Constituents of the Blood on the Contraction of the Heart. Journal of Physiology 4, 29-42 23.

Riordan, J. R., Rommens, J. M., Kerem, B., Alon, N., Rozmahel, R., GrZelczaK, Z., Zielenski, J., LoK, S., Plavsic, N., Chou, J. L., Drumm, M. L., IAnnuzZi, M. 
C., Collins, F. S. \& Tsui, L. C. (1989). Identification of the cystic fibrosis gene: cloning and characterization of complementary DNA. Science 245, 1066-1073. RIORDAN, J. R. (2008). CFTR function and prospects for therapy. Annual Review of Biochemistry 77, 701-726.

Roessler, M. \& Muller, V. (2002). Chloride, a new environmental signal molecule involved in gene regulation in a moderately halophilic bacterium, Halobacillus halophilus. Journal of Bacteriology 184, 6207-6215.

Roessler, M., Sewald, X. \& Muller, V. (2003). Chloride dependence of growth in bacteria. Federation of European Microbiological Societies Microbiology Letters 225, 161-165.

Rommens, J. M., Iannuzzi, M. C., Kerem, B., Drumm, M. L., Melmer, G., Dean, M., Rozmahel, R., Cole, J. L., Kennedy, D., Hidaka, N., Zsiga, M., Buchwald, M., Riordan, J. R., Tsui, L.-C. \& Collins, F. (1989). Identification of the cystic fibrosis gene: chromosome walking and jumping. Science 245, 10591065.

Rommens, J. M., Dho, S., Bear, C. E., KARTner, N., Kennedy, D., Riordan, J. R., TSUI, L. C. \& FosKETT, J. K. (1991). cAMP-inducible chloride conductance in mouse fibroblast lines stably expressing the human cystic fibrosis transmembrane conductance regulator. Proceedings of the National Academy of Sciences of the United States of America 88, 7500-7504.

RoSENFELD, L. (2003). William Prout: early 19th century physician-chemist. Clinical Chemistry 49, 699-705.

Rozansky, D. J., Wang, J., Doan, N., Purdy, T., Faulk, T., Bhargava, A., Dawson, K. \& PEARCE, D. (2002). Hypotonic induction of SGK1 and Na+ transport in A6 cells. American Journal of Physiology: Renal Physiology 283, F105-113. 
RuSSELl, J. M. (1979). Chloride and sodium influx: a coupled uptake mechanism in the squid giant axon. Journal of General Physiology 73, 801-818.

Russell, J. M. (2000). Sodium-potassium-chloride cotransport. Physiological Reviews 80, 211-276.

Russell, J. M. (2010). Chapter 2 - Sodium-Coupled Chloride Cotransporters: Discovery and Newly Emerging Concepts. In Physiology and Pathology of Chloride Transporters and Channels in the Nervous System, pp. 17-26. Academic Press, San Diego, CA.

SABIROV, R. Z., Merzlyak, P. G., ISlAm, M. R., OKADA, T. \& OKADA, Y. (2016). The properties, functions, and pathophysiology of maxi-anion channels. Pflügers Archives - European Journal of Physiology 468, 405-420.

Sala-Rabanal, M., Yurtsever, Z., Berry, K. N. \& Brett, T. J. (2015). Novel Roles for Chloride Channels, Exchangers, and Regulators in Chronic Inflammatory Airway Diseases. Mediators of Inflammation 2015, 497387.

SANDERs, J. W., Venema, G. \& KoK, J. (1997). A chloride-inducible gene expression cassette and its use in induced lysis of Lactococcus lactis. Applied and Environmental Microbiology 63, 4877-4882.

SANDERS, J. W., Venema, G., KoK, J. \& LeENHOUTS, K. (1998). Identification of a sodium chloride-regulated promoter in Lactococcus lactis by single-copy chromosomal fusion with a reporter gene. Molecular and General Genetics 257, $681-685$.

Sangan, P., RAJendran, V. M., Geibel, J. P. \& Binder, H. J. (2002). Cloning and expression of a chloride-dependent $\mathrm{Na}+\mathrm{H}+$ exchanger. Journal of Biological Chemistry 277, 9668-9675. 
Schreiber, R., Faria, D., Skryabin, B. V., Wanitchakool, P., Rock, J. R. \& KunZELMANN, K. (2015). Anoctamins support calcium-dependent chloride secretion by facilitating calcium signaling in adult mouse intestine. Pflügers Archives - European Journal of Physiology 467, 1203-1213.

SCHREIBER, R. \& KUNZELMANN, K. (2016). Expression of anoctamins in retinal pigment epithelium (RPE). Pflügers Archives - European Journal of Physiology 468, $1921-1929$.

Seavilleklein, G., Amer, N., Evagelidis, A., Chappe, F., Irvine, T., Hanrahan, J. W. \& CHAPPE, V. (2008). PKC phosphorylation modulates PKA-dependent binding of the R domain to other domains of CFTR. American Journal of Physiology Cell Physiology 295, C1366-1375.

Sewald, X., Saum, S. H., Palm, P., Pfeiffer, F., Oesterhelt, D. \& Muller, V. (2007). Autoinducer-2-producing protein LuxS, a novel salt- and chlorideinduced protein in the moderately halophilic bacterium Halobacillus halophilus. Applied and Environmental Microbiology 73, 371-379.

Shapiro, L. \& DinAREllo, C. A. (1997). Hyperosmotic stress as a stimulant for proinflammatory cytokine production. Experimental Cell Research 231, 354362.

Sharma, N., LARUsch, J., Sosnay, P. R., GotTschalK, L. B., LOPEZ, A. P., Pellicore, M. J., Evans, T., Davis, E., Atalar, M., Na, C. H., Rosson, G. D., Belchis, D., Milewski, M., Pandey, A. \& Cutting, G. R. (2016). A sequence upstream of canonical PDZ-binding motif within CFTR COOH-terminus enhances NHERF1 interaction. American Journal of Physiology Lung Cellular and Molecular Physiology 311, L1170-L1182. 
Shcheynikov, N., Son, A., Hong, J. H., Yamazaki, O., Ohana, E., Kurtz, I., Shin, D. M. \& MUALLEM, S. (2015). Intracellular Cl- as a signaling ion that potently regulates $\mathrm{Na}+\mathrm{HCO} 3-$ transporters. Proceedings of the National Academy of Sciences of the United States of America 112, E329-337.

Shekarabi, M., Zhang, J., Khanna, A. R., Ellison, D. H., Delpire, E. \& Kahle, K. T. (2017). WNK Kinase Signaling in Ion Homeostasis and Human Disease. Cell Metabolism 25, 285-299.

Simoes, F., Ousingsawat, J., Wanitchakool, P., Fonseca, A., Cabrita, I., Benedetto, R., Schreiber, R. \& KunZelmann, K. (2018). CFTR supports cell death through ROS-dependent activation of TMEM16F (anoctamin 6). Pflügers Archives - European Journal of Physiology 470, 305-314.

Simon, D. B., Bindra, R. S., Mansfield, T. A., Nelson-Williams, C., Mendonca, E., Stone, R., Schurman, S., Nayir, A., Alpay, H., BaKkaloglu, A., Rodriguez-Soriano, J., Morales, J. M., Sanjad, S. A., Taylor, C. M., Pilz, D., ET AL. (1997). Mutations in the chloride channel gene, CLCNKB, cause Bartter's syndrome type III. Nature Genetics 17, 171-178.

Sirianant, L., Ousingsawat, J., Wanitchakool, P., Schreiber, R. \& KunZelmann, K. (2016). Cellular volume regulation by anoctamin 6: $\mathrm{Ca}(2)(+)$, phospholipase A2 and osmosensing. Pflügers Archives - European Journal of Physiology 468, $335-349$.

Skals, M., Jensen, U. B., Ousingsawat, J., Kunzelmann, K., Leipziger, J. \& PRAETORIUS, H. A. (2010). Escherichia coli alpha-hemolysin triggers shrinkage of erythrocytes via $\mathrm{K}(\mathrm{Ca}) 3.1$ and TMEM16A channels with subsequent phosphatidylserine exposure. Journal of Biological Chemistry 285, 1555715565. 
Skeggs, L. T., JR., Marsh, W. H., Kahn, J. R. \& Shumway, N. P. (1954). The existence of two forms of hypertensin. Journal of Experimental Medicine 99, $275-282$.

SkegGS, L. T., JR., KAHN, J. R. \& ShUMWAY, N. P. (1956). The preparation and function of the hypertensin-converting enzyme. Journal of Experimental Medicine 103, 295-299.

Smulyan, H. \& VillarReAL, D. (2019). The Birth of Angiotensin: An International Compromise. American Journal of the Medical Sciences 357, 179-183.

Spitzner, M., Martins, J. R., Soria, R. B., Ousingsawat, J., ScheidT, K., SCHREIBER, R. \& KunZELmAnN, K. (2008). Eag1 and Bestrophin 1 are upregulated in fast-growing colonic cancer cells. Journal of Biological Chemistry 283, 7421-7428.

SRIVAstava, M., Eidelman, O. \& Pollard, H. B. (1999). Pharmacogenomics of the cystic fibrosis transmembrane conductance regulator (CFTR) and the cystic fibrosis drug CPX using genome microarray analysis. Molecular Medicine 5, $753-767$.

Statland, J., PhilliPS, L. \& TRIVEDI, J. R. (2014). Muscle channelopathies. Neurologic Clinics 32, 801-815.

STAUBER, T. (2015). The volume-regulated anion channel is formed by LRRC8 heteromers - molecular identification and roles in membrane transport and physiology. Biological Chemistry 396, 975-990.

Succol, F., Fiumelli, H., Benfenati, F., Cancedda, L. \& Barberis, A. (2012). Intracellular chloride concentration influences the GABAA receptor subunit composition. Nature Communications 3, 738. 
Suetterlin, K., MannikKo, R. \& Hanna, M. G. (2014). Muscle channelopathies: recent advances in genetics, pathophysiology and therapy. Current Opinion in Neurology 27, 583-590.

Sun, Q., Wu, Y., Jonusaite, S., Pleinis, J. M., Humphreys, J. M., He, H., Schellinger, J. N., AKella, R., Stenesen, D., Kramer, H., Goldsmith, E. J. \& RodAN, A. R. (2018). Intracellular Chloride and Scaffold Protein Mo25 Cooperatively Regulate Transepithelial Ion Transport through WNK Signaling in the Malpighian Tubule. Journal of the American Society of Nephrology 29, $1449-1461$.

Tabary, O., Escotte, S., Couetil, J. P., Hubert, D., Dusser, D., Puchelle, E. \& JACQUOT, J. (2000). High susceptibility for cystic fibrosis human airway gland cells to produce IL-8 through the I kappa B kinase alpha pathway in response to extracellular $\mathrm{NaCl}$ content. Journal of Immunology 164, 3377-3384.

Taminelli, G. L., Sotomayor, V., Valdivieso, A. G., Teiber, M. L., Marin, M. C. \& SANTA-COLOMA, T. A. (2008). CISD1 codifies a mitochondrial protein upregulated by the CFTR channel. Biochemical and Biophysical Research Communications 365, 856-862.

Terker, A. S., Zhang, C., Erspamer, K. J., Gamba, G., Yang, C. L. \& Ellison, D. H. (2016). Unique chloride-sensing properties of WNK4 permit the distal nephron to modulate potassium homeostasis. Kidney International 89, 127-134.

TiAn, Y., SchreIBER, R. \& KunZELMANN, K. (2012). Anoctamins are a family of $\mathrm{Ca}^{2+}$ activated $\mathrm{Cl}^{-}$channels. Journal of Cell Science 125, 4991-4998.

TOMASKOVA, Z. \& ONDRIAS, K. (2010). Mitochondrial chloride channels--What are they for? Federation of European Biochemical Societies Letters 584, 20852092. 
Treharne, K. J., Marshall, L. J. \& Mehta, A. (1994). A novel chloride-dependent GTP-utilizing protein kinase in plasma membranes from human respiratory epithelium. American Journal of Physiology 267, L592-601.

Treharne, K. J., Crawford, R. M. \& Mehta, A. (2006). CFTR, chloride concentration and cell volume: could mammalian protein histidine phosphorylation play a latent role? Experimental Physiology 91, 131-139.

TuREKIAN, K. K. (1968). Oceans, First Edition edition. Prentice-Hall, Englewood Cliffs, NJ

Valdivieso, A. G., Marcucci, F., Taminelli, G., Guerrico, A. G., Alvarez, S., Teiber, M. L., Dankert, M. A. \& SAnta-Coloma, T. A. (2007). The expression of the mitochondrial gene MT-ND4 is downregulated in cystic fibrosis. Biochemical and Biophysical Research Communications 356, 805-809.

VALDIVIESO, A. G. (2009). [Modulación de la expresión del gen MTND4 mitocondrial mediada por la actividad del CFTR] Ph.D. thesis, Universidad de Buenos Aires.

Valdivieso, A. G., Marin, M. C., Clauzure, M. \& Santa-Coloma, T. A. (2011). Measurement of cystic fibrosis transmembrane conductance regulator activity using fluorescence spectrophotometry. Analytical Biochemistry 418, 231-237.

Valdivieso, A. G., Clauzure, M., Marin, M. C., Taminelli, G. L., Massip Copiz, M. M., SAnchez, F., Schulman, G., Teiber, M. L. \& SAnTA-Coloma, T. A. (2012). The mitochondrial complex I activity is reduced in cells with impaired cystic fibrosis transmembrane conductance regulator (CFTR) function. PloS One 7, e48059.

VAldivieso, A. G. \& SANTA-COLOMA, T. A. (2013). CFTR activity and mitochondrial function. Redox Biology 1, 190-202. 
Valdivieso, A. G., Clauzure, M., Massip Copiz, M. M., Cancio, C. E., Mori, C., Asensio, C. \& Santa Coloma, T. A. (2015). Abstract 66 [Rol del anión Cloruro como segundo mensajero en la modulación de la expresión de genes específicos]. 60th meeting of the Argentine Society of Clinical Investigation (SAIC). november 18-21, 2015. Mar del Plata, Argentina. . Medicina (Buenos Aires) 75 (Suppl. II), 55-55.

Valdivieso, A. G., Clauzure, M., Massip-Copiz, M. \& Santa-Coloma, T. A. (2016). The Chloride Anion Acts as a Second Messenger in Mammalian Cells Modifying the Expression of Specific Genes. Cellular Physiology and Biochemistry 38, 49-64.

Valdivieso, A. G., Mori, C., Clauzure, M., Massip-Copiz, M. \& Santa-Coloma, T. A. (2017). CFTR modulates RPS27 gene expression using chloride anion as signaling effector. Archives of Biochemistry and Biophysics 633, 103-109. Valdivieso, A. G., Clauzure, M., Massip-Copiz, M. M., Cancio, C. E., Asensio, C. J. A., Mori, C. \& SANTA-COLOMA, T. A. (2019). Impairment of CFTR activity in cultured epithelial cells upregulates the expression and activity of LDH resulting in lactic acid hypersecretion. Cellular and Molecular Life Sciences.

Wanitchakool, P., Wolf, L., Koehl, G. E., Sirianant, L., Schreiber, R., KulKarni, S., Duvvuri, U. \& KunZelmann, K. (2014). Role of anoctamins in cancer and apoptosis. Philosophical Transactions of the Royal Society of London B: Biological Sciences 369, doi: 10.1098/rstb.2013.0096.

Wanitchakool, P., Ousingsawat, J., Sirianant, L., MacAulay, N., Schreiber, R. \& KunZElmann, K. (2016). $\mathrm{Cl}^{-}$channels in apoptosis. European Biophysics Journal 45, 599-610. 
Wanitchakool, P., Ousingsawat, J., Sirianant, L., Cabrita, I., Faria, D., SCHREIBER, R. \& Kunzelmann, K. (2017). Cellular defects by deletion of ANO10 are due to deregulated local calcium signaling. Cellular Signalling 30, $41-49$.

Watson, M. J., Lee, S. L., Marklew, A. J., Gilmore, R. C., Gentzsch, M., SAssano, M. F., Gray, M. A. \& TARRAN, R. (2016). The Cystic Fibrosis Transmembrane Conductance Regulator (CFTR) Uses its C-Terminus to Regulate the A2B Adenosine Receptor. Scientific Reports 6, 27390.

WeSt, J. B. (1997). Best and Taylor's Physiological Basis of Medical Practice, 12th Edition edition. Williams and Wilkins., Baltimore, MD.

Whitlock, J. M. \& Hartzell, H. C. (2016). A Pore Idea: the ion conduction pathway of TMEM16/ANO proteins is composed partly of lipid. Pflügers Archives European Journal of Physiology 468, 455-473.

WiLlumsen, N. J., DAVIS, C. W. \& BoucheR, R. C. (1994). Selective response of human airway epithelia to luminal but not serosal solution hypertonicity. Possible role for proximal airway epithelia as an osmolality transducer. Journal of Clinical Investigation 94, 779-787.

Wolf-Watz, M., Backstrom, S., Grundstrom, T., SAuer, U. \& Hard, T. (2001). Chloride binding by the AML1/Runx1 transcription factor studied by NMR. Federation of European Biochemical Societies Letters 488, 81-84.

XIE, Y. \& SCHAFER, J. A. (2004). Inhibition of ENaC by intracellular $\mathrm{Cl}^{-}$in an $\mathrm{MDCK}$ clone with high ENaC expression. American Journal of Physiology: Renal Physiology 287, F722-731.

Xu, B.-E., English, J. M., Wilsbacher, J. L., Stippec, S., Goldsmith, E. J. \& Cobb, M. H. (2000). WNK1, a novel mammalian serine/threonine protein kinase 
lacking the catalytic lysine in subdomain II. Journal of Biological Chemistry 275, 16795-16801.

Xu, Y., Clark, J. C., Aronow, B. J., Dey, C. R., Liu, C., Wooldridge, J. L. \& WhitsetT, J. A. (2003). Transcriptional adaptation to cystic fibrosis transmembrane conductance regulator deficiency. Journal of Biological Chemistry 278, 7674-7682.

Yang, C.-L., LiU, X., Paliege, A., Zhu, X., Bachmann, S., Dawson, D. C. \& ELLISON, D. H. (2007). WNK1 and WNK4 modulate CFTR activity. Biochemical and Biophysical Research Communications 353, 535-540.

Yang, H., Huang, L. Y., Zeng, D. Y., Huang, E. W., Liang, S. J., Tang, Y. B., Su, Y. X., TaO, J., Shang, F., Wu, Q. Q., Xiong, L. X., Lv, X. F., Liu, J., Guan, Y. Y. \& ZHOU, J. G. (2012). Decrease of intracellular chloride concentration promotes endothelial cell inflammation by activating nuclear factor-kappaB pathway. Hypertension 60, 1287-1293.

Yang, T., Park, J. M., Arend, L., Huang, Y., Topaloglu, R., Pasumarthy, A., Praetorius, H., Spring, K., Briggs, J. P. \& Schnermann, J. (2000). Low chloride stimulation of prostaglandin E2 release and cyclooxygenase-2 expression in a mouse macula densa cell line. Journal of Biological Chemistry 275, 37922-37929.

Yu, H., Zhang, Z., Lis, A., PEnNer, R. \& Fleig, A. (2013). TRPM7 is regulated by halides through its kinase domain. Cellular and Molecular Life Sciences 70, $2757-2771$.

Yuan, A., Dourado, M., Butler, A., Walton, N., Wei, A. \& Salkoff, L. (2000). SLO-2, a K ${ }^{+}$channel with an unusual $\mathrm{Cl}^{-}$dependence. Nature Neuroscience $\mathbf{3}$, $771-779$. 
ZHANG, C., WU, S. \& XU, D. (2013). Catalytic mechanism of angiotensin-converting enzyme and effects of the chloride ion. Journal of Physical Chemistry. B 117, $6635-6645$.

Zhang, Y. L., Chen, P. X., Guan, W. J., Guo, H. M., QIu, Z. E., Xu, J. W., LuO, Y. L., Lan, C. F., Xu, J. B., HaO, Y., Tan, Y. X., Ye, K. N., Lun, Z. R., ZhaO, L., ZhU, Y. X., ET AL. (2018). Increased intracellular $\mathrm{Cl}(-)$ concentration promotes ongoing inflammation in airway epithelium. Mucosal Immunology 11, 11491157.

Zhou, J. G., Ren, J. L., QIU, Q. Y., He, H. \& GuAN, Y. Y. (2005). Regulation of intracellular $\mathrm{Cl}^{-}$concentration through volume-regulated $\mathrm{ClC}-3$ chloride channels in A10 vascular smooth muscle cells. Journal of Biological Chemistry 280, 7301-7308. 


\section{FIGURE LEGENDS}

Fig. 1. Mechanism involving $\mathrm{Cl}^{-}$signalling that induces interleukin-1 $\beta$ (IL-1 $\beta$ ) hypersecretion. Initially a $\mathrm{Cl}^{-}$channel $\left(\mathrm{Cl}^{-} \mathrm{Ch}\right)$ is stimulated through some external signal $\mathrm{X}$, as for example the adrenergic receptor in the case of the cystic fibrosis transmembrane conductance regulator (CFTR). The activation/inhibition of the $\mathrm{Cl}^{-}$channel modulates $\mathrm{Cl}^{-}$concentration, which in turn is sensed by a $\mathrm{Cl}^{-}$-sensitive kinase such as serum glucocorticoid regulated kinase 1 (SGK1). Increased $\left[\mathrm{Cl}^{-}\right]$stimulates SGK1 activity, which in turn modulates the nuclear factor kappa B (NF- $\kappa \mathrm{B})$ activation, although its exact site of action remains to be determined. This results in induction of IL-1 $\beta$ gene expression and later maturation and secretion through the NLRP3 (nucleotide-binding oligomerization domain-like receptor family, pyrin domain containing 3) inflammasome. Increased IL-1 $\beta$ secretion in turn produces an autocrine positive-feedback loop that enhances its own expression, creating a proinflammatory state This IL-1 $\beta$ signal inhibits the activity of mitochondrial Complex I, induces oxidative stress, and leads to the expression of IL-1 $1 \beta$-specific genes. In addition, other genes and kinases related to IL-1 $\beta$ are activated, including SRC proto-oncogene, nonreceptor tyrosine kinase (c-Src), which modulates mucin 1 (MUC1), among many other proteins $(\mathrm{x}) . \mathrm{IL}-1 \beta$ is not the only signal stimulated by $\mathrm{Cl}^{-}$; many genes are now thought to be under $\mathrm{Cl}^{-}$modulation. $\mathrm{Cl}^{-} \mathrm{Ch}: \mathrm{Cl}^{-}$channel; IKBalpha: nuclear factor of kappa light polypeptide gene enhancer in B-cells inhibitor, alpha; IKK: IкB kinase; SGK1: serum/glucocorticoid regulated kinase 1;IL-1 $\beta$ : interleukin-1 $\beta$; mRNAs: messenger RNAs; NF-кB: nuclear factor kappa B; x: any channel or protein. Figure created using the software Network Painter (Karr et al., 2015). 
Table 1. Examples of proteins affected by $\mathrm{Cl}^{-}$through direct binding of the anion. Additional examples of $\mathrm{Cl}^{-}$-binding proteins and a detailed discussion of the mechanisms involved in its binding to proteins can be found in the Coleman (1990).

\begin{tabular}{|c|c|c|c|c|}
\hline $\begin{array}{l}\text { Protein } \\
\text { symbol }\end{array}$ & Name & Protein function & $\begin{array}{l}\mathrm{Cl}^{-} \\
\text {function }\end{array}$ & References \\
\hline ACE & $\begin{array}{l}\text { Angiotensin converting } \\
\text { enzyme }\end{array}$ & Enzyme, hypertension & $\begin{array}{l}\text { Activator or } \\
\text { inhibitor } \\
\text { depending } \\
\text { on substrate }\end{array}$ & $\begin{array}{l}\text { Coleman (1990); Liu } \\
\text { et al. }(2001) ; \\
\text { Masuyer } \text { et al.(2014) }\end{array}$ \\
\hline PAA & Pancreatic $\alpha$-amylase & $\begin{array}{l}\text { Enzyme, hydrolyses } \\
\text { oligosaccharides }\end{array}$ & $\begin{array}{l}\text { Allosteric } \\
\text { activator }\end{array}$ & $\begin{array}{l}\text { Claisse } \text { et al. }(2016) ; \\
\text { Coleman }(1990) ; \\
\text { Maurus et al. }(2005)\end{array}$ \\
\hline PII, OEC & $\begin{array}{l}\text { Photosynthetic oxygen- } \\
\text { evolving complex }\end{array}$ & $\begin{array}{l}\text { Enzyme complex involved } \\
\text { in photosynthesis }\end{array}$ & Activator & $\begin{array}{l}\text { Coleman (1990); } \\
\text { Murray et al. (2008); } \\
\text { Pokhrel et al. (2011) }\end{array}$ \\
\hline GadB & $\begin{array}{l}\text { Glutamate } \\
\text { decarboxylase }\end{array}$ & Enzyme, $\mathrm{pH}$ regulation & Activator & $\begin{array}{l}\text { De Biase \& } \\
\text { Pennacchietti (2012); } \\
\text { Sanders et al. (1998) }\end{array}$ \\
\hline RUNX1 & $\begin{array}{l}\text { Runt related } \\
\text { transcription factor } 1\end{array}$ & Transcription factor & Activator & $\begin{array}{l}\text { Backstrom et al. } \\
\text { (2002); Wolf-Watz } \\
\text { et al. }(2001)\end{array}$ \\
\hline SGK1 & $\begin{array}{l}\text { Serum glucocorticoid } \\
\text { regulated kinase } 1\end{array}$ & $\begin{array}{l}\text { Protein kinase, cell } \\
\text { signalling }\end{array}$ & $\begin{array}{l}\text { Activator } \\
\text { unknown } \\
\text { binding site }\end{array}$ & Zhang et al. (2018) \\
\hline WNK1 & With no lysine $(\mathrm{K}) 1$ & $\begin{array}{l}\text { Protein kinase, cell } \\
\text { signalling }\end{array}$ & Inhibitor & Piala et al. (2014) \\
\hline WNK4 & With no lysine $(\mathrm{K}) 4$ & $\begin{array}{l}\text { Protein kinase, cell } \\
\text { signalling }\end{array}$ & Inhibitor & Chen et al. (2019) \\
\hline MPO & Myeloperoxidase & $\begin{array}{l}\text { Peroxidase, produces } \\
\text { hypochlorous acid }(\mathrm{HOCl}) \\
\text { from } \mathrm{H}_{2} \mathrm{O}_{2} \text { and } \mathrm{Cl}^{-}\end{array}$ & $\begin{array}{l}\text { Substrate, } \\
\text { inhibitor }\end{array}$ & $\begin{array}{l}\text { Coleman (1990); } \\
\text { Fiedler et al. }(2000)\end{array}$ \\
\hline
\end{tabular}


Table 2. Genes/proteins indirectly regulated by $\mathrm{Cl}^{-}$: some examples of $\mathrm{Cl}^{-}$-dependent genes and proteins.

\begin{tabular}{|c|c|c|c|c|}
\hline $\begin{array}{l}\text { Gene or } \\
\text { protein symbol }\end{array}$ & Name & $\begin{array}{l}\text { Gene product } \\
\text { function }\end{array}$ & $\begin{array}{l}\mathbf{C l}^{-} \text {function } \\
\text { (increased }\left[\mathrm{Cl}^{-}\right] \text {) }\end{array}$ & Reference \\
\hline $\operatorname{gadB}$ & $\begin{array}{l}\text { Glutamate } \\
\text { decarboxylase beta }\end{array}$ & $\begin{array}{l}\text { Glutamate } \\
\text { decarboxylase }\end{array}$ & Upregulation & $\begin{array}{l}\text { De Biase \& } \\
\text { Pennacchietti } \\
\text { (2012); Sanders } \\
\text { et al. }(1998)\end{array}$ \\
\hline $\operatorname{gadC}$ & $\begin{array}{l}\text { Glutamate/gamma- } \\
\text { aminobutyrate } \\
\text { antiporter }\end{array}$ & $\begin{array}{l}\text { Glu/GABA } \\
\text { antiporter }\end{array}$ & Upregulation & $\begin{array}{l}\text { De Biase \& } \\
\text { Pennacchietti } \\
\text { (2012); Sanders } \\
\text { et al. }(1998)\end{array}$ \\
\hline$f l i C$ & Flagellin & Ciliary movement & Upregulation & $\begin{array}{l}\text { Roessler \& } \\
\text { Muller (2002) }\end{array}$ \\
\hline $\begin{array}{l}\text { COX2/ } \\
\text { PTGS2 }\end{array}$ & $\begin{array}{l}\text { Cyclooxygenase } \\
\text { 2/prostaglandin- } \\
\text { endoperoxide } \\
\text { synthase } 2\end{array}$ & $\begin{array}{l}\text { Prostaglandin } \mathrm{G} / \mathrm{H} \\
\text { synthase }\end{array}$ & $\begin{array}{l}\text { Down- } \\
\text { regulation }\end{array}$ & $\begin{array}{l}\text { Cheng et al. } \\
\text { (2000); Yang et } \\
\text { al. 2000) }\end{array}$ \\
\hline$G L R X 5$ & Glutaredoxin 5 & $\begin{array}{l}\text { Mitochondrial } \\
\text { protein, iron-sulfur } \\
\text { cluster biogenesis }\end{array}$ & Upregulation & $\begin{array}{l}\text { Valdivieso et al. } \\
\text { (2016) }\end{array}$ \\
\hline$R P S 27$ & $\begin{array}{l}\text { Ribosomal protein } \\
\text { S27 }\end{array}$ & $\begin{array}{l}18 \mathrm{~S} \text { rRNA } \\
\text { processing }\end{array}$ & $\begin{array}{l}\text { Biphasic } \\
\text { regulation }\end{array}$ & $\begin{array}{l}\text { Valdivieso et al. } \\
(2016)\end{array}$ \\
\hline$I L I B$ & Interleukin-1 $\beta$ & $\begin{array}{l}\text { Proinflammatory } \\
\text { factor }\end{array}$ & Upregulation & $\begin{array}{l}\text { Clauzure et al. } \\
\text { (2017) }\end{array}$ \\
\hline CFTR & $\begin{array}{l}\text { Cystic fibrosis } \\
\text { transmembrane } \\
\text { conductance regulator }\end{array}$ & $\begin{array}{l}\mathrm{Cl}^{-} \text {channel and } \mathrm{Cl}^{-} \\
\text {sensor }\end{array}$ & Activation & $\begin{array}{l}\text { Broadbent et al. } \\
\text { (2015); Jiang et } \\
\text { al. (1998) }\end{array}$ \\
\hline GABAA receptor & GABA A receptors & $\begin{array}{l}\text { Ligand-gated } \mathrm{Cl}^{-} \\
\text {channel }\end{array}$ & $\begin{array}{l}\text { Upregulates } \\
\text { alpha 3-1 and } \\
\text { delta subunits }\end{array}$ & $\begin{array}{l}\text { Succol et al. } \\
(2012)\end{array}$ \\
\hline$P 21 / C D K N 1 A$ & $\begin{array}{l}\text { Cyclin dependent } \\
\text { kinase inhibitor 1A }\end{array}$ & $\begin{array}{l}\text { Signalling kinase } \\
\text { inhibitor }\end{array}$ & $\begin{array}{l}\text { Inhibits p } 21 \\
\text { expression }\end{array}$ & $\begin{array}{l}\text { Miyazaki et al. } \\
(2008)\end{array}$ \\
\hline $\begin{array}{l}\text { NKCC1/ } \\
\text { SLC12A2 }\end{array}$ & $\begin{array}{l}\text { Solute carrier family } \\
12 \text { member } 2\end{array}$ & $\begin{array}{l}\text { Basolateral } \mathrm{Na}^{+}-\mathrm{K}^{+}- \\
\mathrm{Cl}^{-} \text {symporter }\end{array}$ & Inhibition & $\begin{array}{l}\text { Russell (2000); } \\
\text { Russell (2010) }\end{array}$ \\
\hline SPAK/ STK39 & $\begin{array}{l}\text { STE20/SPS1 homolog } \\
\text { (yeast)/ } \\
\text { serine/threonine } \\
\text { kinase } 39\end{array}$ & $\begin{array}{l}\text { Serine threonine } \\
\text { kinase }\end{array}$ & $\begin{array}{l}\text { Inhibition of } \\
\text { WNK4/SPAK } \\
\text { pathway }\end{array}$ & $\begin{array}{l}\text { Shekarabi et al. } \\
\text { (2017) }\end{array}$ \\
\hline SLC26A family & $\begin{array}{l}\text { Solute carrier family } \\
26 \text { members }\end{array}$ & $\begin{array}{l}\mathrm{Cl}^{-} / \mathrm{HCO}_{3}^{-} \\
\text {exchangers }\end{array}$ & $\begin{array}{l}\text { Inhibition of } \\
\text { WNK4/SPAK } \\
\text { pathway }\end{array}$ & $\begin{array}{l}\text { Shekarabi et al. } \\
\text { (2017) }\end{array}$ \\
\hline SLO-2 & $\begin{array}{l}\mathrm{K}+-\mathrm{Na}+\text {-activated } \\
\text { channel subfamily } \mathrm{T}\end{array}$ & $\mathrm{K}^{+}$channel & Activator & $\begin{array}{l}\text { Yuan et al. } \\
(2000)\end{array}$ \\
\hline $\mathrm{ENaC}$ & $\begin{array}{l}\text { Epithelial sodium } \\
\text { channel }\end{array}$ & $\begin{array}{l}\text { Ligand-gated } \\
\text { sodium channel }\end{array}$ & $\begin{array}{l}\text { Gene/protein } \\
\text { inhibition }\end{array}$ & $\begin{array}{l}\text { Niisato et al. } \\
\text { (2004); Niisato } \\
\text { et al. }(2007) ; \\
\text { Xie \& Schafer } \\
(2004)\end{array}$ \\
\hline TRPM7 & $\begin{array}{l}\text { Transient receptor } \\
\text { potential melastatin } 7\end{array}$ & $\begin{array}{l}\text { Divalent-selective } \\
\text { cation channel }\end{array}$ & Inhibition & Yu et al. (2013) \\
\hline
\end{tabular}




\begin{tabular}{|l|l|l|l|l|}
\hline ITGB2/ß2 integrin & Integrin subunit beta 2 & $\begin{array}{l}\text { Cellular adhesion } \\
\text { and cell surface } \\
\text { signalling }\end{array}$ & $\begin{array}{l}\text { Tumour necrosis } \\
\text { factor (TNF)- } \\
\text { induced } \beta 2 \\
\text { integrin } \\
\text { activation }\end{array}$ & $\begin{array}{l}\text { Menegazzi } \text { et al. } \\
(2000)\end{array}$ \\
\hline
\end{tabular}

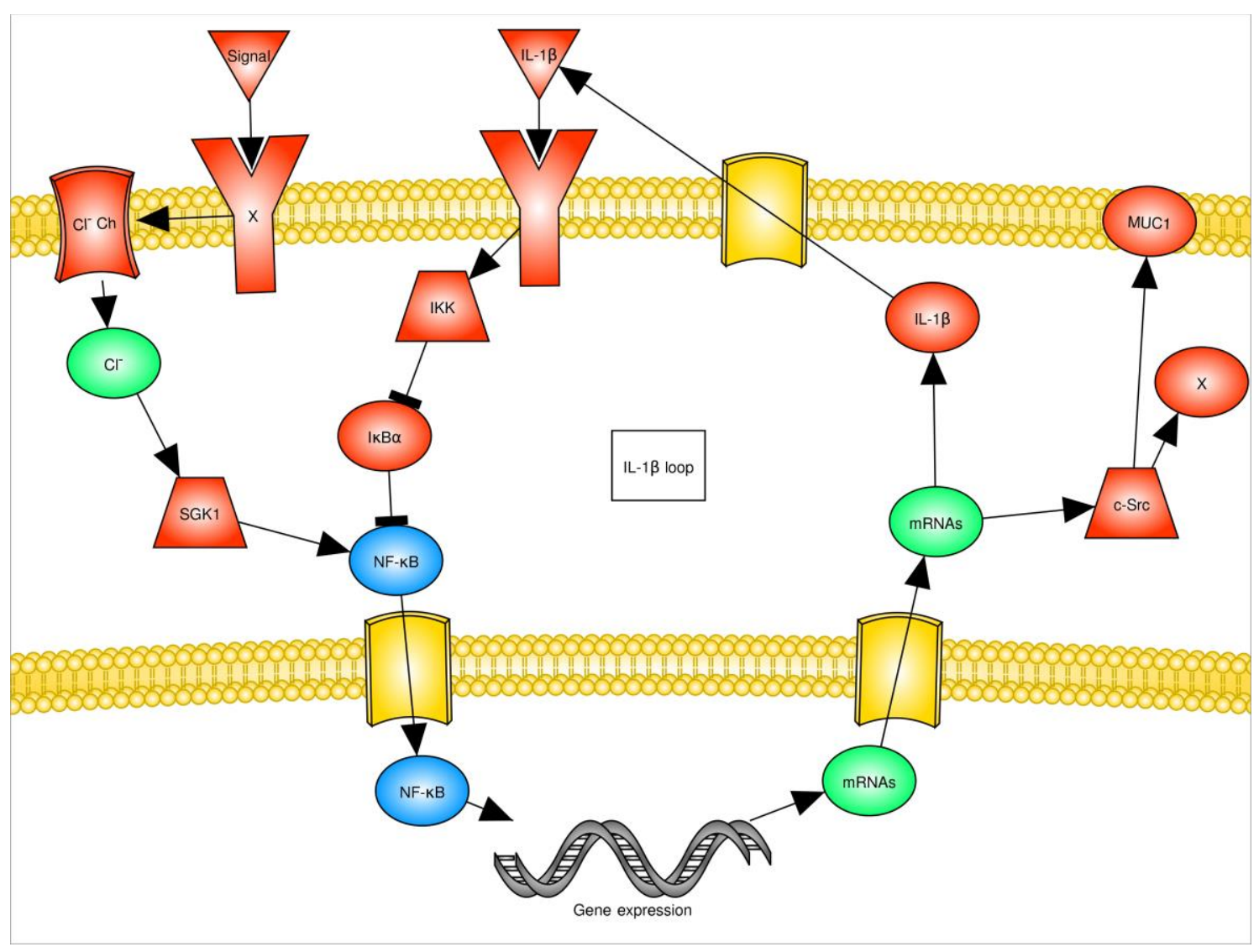

Figure 1 